\title{
Pyrometallurgical upgrading of PGM-rich leach residues from the Western Platinum Base Metals Refinery through roasting
}

\author{
G.A. Bezuidenhout ${ }^{1}$, J.J. Eksteen ${ }^{2} \dagger$, G. Akdogan $^{3}$, S.M. Bradshaw ${ }^{3}$, J.P.R. De Villiers ${ }^{4}$
}

1. Lonmin, Process Division, Private Bag X508, Marikana, 0284, South Africa

2. Department of Metallurgical and Minerals Engineering, Western Australian School of Mines, Curtin University, GPO Box U1987, Perth, WA 6845, Australia

3. Department of Process Engineering, University of Stellenbosch, Private Bag X1, Matieland, Stellenbosch, 7602, South Africa

4. Department of Materials Science \& Metallurgical Engineering, University of Pretoria, Pretoria, 0002, South Africa

*Corresponding Author: Rian.Bezuidenhout@lonmin.com

$†$ Prof JJ Eksteen serves as Professor (Extraordinary) at the University of Stellenbosch.

\begin{abstract}
The production of Platinum Group Metals (PGM) normally entails the smelting of PGM flotation concentrates, converting of the furnace matte and removal of the bulk of the $\mathrm{Ni}, \mathrm{Cu}, \mathrm{Co}, \mathrm{S}$ and $\mathrm{Fe}$ through atmospheric and pressure leaching in a base metals refinery to produce a PGM-rich concentrate. A number of impurities, mostly $\mathrm{Se}, \mathrm{Te}, \mathrm{As}, \mathrm{Bi}, \mathrm{Os}$ and $\mathrm{Pb}$, are not removed significantly during the oxidising leach process in sulphuric acid media. In addition slag inclusions in matte leads to contamination of the PGM residues with silica, fayalite, magnetite and trevorite phases. Furthermore some $\mathrm{Cu}, \mathrm{Ni}, \mathrm{Fe}$ and $\mathrm{S}$ also remain. For this reason a typical Precious Metal Refinery (PMR) feed material contains less than 65\% PGMs. The PMR is based on a chloride process and requires contaminants to be within narrow specification limits to prevent the formation of PGM residues that must be reprocessed or tolled, leading to poor first pass metal efficiencies and extending the duration of the production pipeline for efficient recovery.

A process has been developed to significantly upgrade the BMR leach residues through pyrometallurgical processing, which include a multistep process of roasting under oxidising atmospheres, a two-step smelting process of the roasted calcine (with engineered slag chemistry and slag-refractory interactions) and subsequent atomisation of the molten alloy which can be fed as a slurry into the $\mathrm{HCl} / \mathrm{Cl}_{2}$ dissolution reactors in the precious metals refinery. These pyrometallurgical steps upgrade the BMR residue from a $45-50 \%$ grade up to an alloy grade of circa $90 \%$ PGMs, whilst removing the most deleterious elements with major process impacts on the PMR.

This paper will focus primarily on the roasting step and it will investigate the thermochemical and mineralogical changes occurring during roasting. These changes were evaluated through a combination of thermochemical modelling and experimental investigation. The roasting step needs to be in an oxidative environment in order to achieve the vaporization of $\mathrm{Se}, \mathrm{Te}, \mathrm{As}$, Os and $\mathrm{S}$. The speciation of PGMs and their vaporization behaviour are presented, as well as the sensitivity of precious metals deportment to changes in roast conditions.
\end{abstract}

\section{Key Words}

Roasting, PGM concentrate, leach residue, volatiles, PGM oxidation, 


\section{BACKGROUND}

A number of base metals removal and refining processes exist to extract and refine base metals from a converter matte to leave behind a PGM rich residue. Of these, the Sherritt ${ }^{\circledR}$ process or various variations of it is most commonly used.

A typical beneficiation sequence, used for example at Western Platinum Ltd, would be:

- Floatation of ore to produce a concentrate (PGM head grade is upgraded from around $3 \mathrm{~g} /$ tonne to $240 \mathrm{~g} /$ tonne)

- Electrical smelting to separate the remaining oxide/ gangue phases form the matte (PGM content upgraded from $240 \mathrm{~g} /$ tonne to around $1500 \mathrm{~g} /$ tonne)

- Converting to remove iron sulphides from the matte phase (PGM content upgraded from around $1500 \mathrm{~g} /$ tonne to $6000 \mathrm{~g} /$ tonne)

- Base metal refining to remove $\mathrm{Ni}$ and $\mathrm{Cu}$ sulphides from matte phase (PGM content upgraded from $6000 \mathrm{~g} /$ tonne to around $65 \%$ content)

- Precious metal refining to separate the 6 individual PGM metals (Pt, Pd, Rh, $\mathrm{Ru}, \mathrm{Ir}$ and $\mathrm{Au}$ ) to $99.9+\%$ purity. Osmium (Os) is also classified as a PGM, while Au is typically not grouped with the Platinum Group Metals, although it is a precious metal. Since the Lonmin Precious Metal Refinery does not recovery Os, but rather Au, the notation for PGM in this paper will refer to $\mathrm{Pt}, \mathrm{Pd}, \mathrm{Rh}, \mathrm{Ru}, \mathrm{Ir}$ and $\mathrm{Au}$.

The concentrate from the BMR process is referred to as PGM concentrate and contains around $65 \%$ PGM (sum of 6 Platinum Group Elements, or PGE). The remaining content of the concentrate contains impurities that reduce efficiency in the subsequent PMR process. The impurities can be classified into the following main groups:

- $\mathrm{SiO}_{2}$ or silica containing minerals.

- Oxides of $\mathrm{Al}_{2} \mathrm{O}_{3}, \mathrm{Cr}_{2} \mathrm{O}_{3}, \mathrm{MgO}, \mathrm{Ni}$ and $\mathrm{Fe}$, often as spinel $\left(\left(\mathrm{M}_{1}{ }^{2+}\right),\left(\mathrm{M}_{2}{ }^{3+}\right)_{2}\right) \mathrm{O}_{4}$ type oxides. The oxides originate from imperfect slag separation during converter matte granulation. This is especially true for the denser spinel type oxides that will tend to settle between the Fayalite type slag and the converter matte.

- Residual Base Metal (mostly $\mathrm{Cu}$ ) Sulphides

- Amphoteric elements (Se, Te, Bi, Sb, As). The so-called "amphoterics" are mostly associated with PGM minerals in the ore. They are poorly removed across the smelter process, or the oxidative and acidic leach processes in the BMR.

- $\mathrm{Pb}$ sulphates or oxy-sulphates. Despite the fact that $\mathrm{Pb}$ is largely removed (around $90 \%$ removal) across the smelter, in both slag and off-gas, the remaining $\mathrm{Pb}$ in converter matte quickly forms a stable sulphate phase that is insoluble in the BMR process.

- Os and $\mathrm{Ag}$, of which Os is particularly problematic, as a contaminant, but also from an occupational health perspective.

The Lonmin PMR process was implemented in 1974 and is based on the classical chemistry of dissolution and precipitation. This technology is sometimes referred to as $1^{\text {st }}$ generation processes. The majority of Platinum producing companies nowadays make use of newer technologies to refine the PGMs by second generation (Solvent Extraction) and third generation (Ion Exchange and Molecular Recognition Technology) processes (Crundwell, et. al, 2011). In the Lonmin dissolution 
and precipitation circuit, the impurities contribute significantly to the formation of residues and effluents that must be reprocessed or tolled to recover PGMs. This leads to poor first pass metal recoveries and extends the duration of the production pipeline for efficient recovery. The recoveries and pipeline is especially impacted on the Other Precious Metals (OPMs) circuits. OPM is a term used to describe the metals of $\mathrm{Ru}, \mathrm{Rh}$ and Ir.

This led to an initiative to develop a process to remove some of the impurities from the PMR feed in order to improve the first pass recoveries and reduce the residues that are created in the PMR process. The process philosophy followed a pyrometallurgical approach in an attempt to remove the bulk of the impurities with only a few processing steps. A process was developed that included the roasting, smelting and atomizing of the PGM concentrate in order to produce an alloy feed to the PMR. A pyrometallurgical process step has the advantage that it targets a wide range of impurities by making use of the noble nature of the PGMs (their resistance to oxidation and low vapour pressures at high temperatures). The results showed that a feed grade of around 90\% PGM to the PMR could be achieved without significant losses of PGMs during the process. This paper will focus on the roasting of PGM concentrates, describing the oxidation and subsequent sublimation behaviour of elements in the PGM concentrate.

The BMR process has an atmospheric oxidative leach to dissolve $\mathrm{Ni}$ sulphides, primarily Heazlewoodite $\left(\mathrm{Ni}_{3} \mathrm{~S}_{2}\right)$, Millerite (NiS) and $\mathrm{Ni}$ alloy (Van Schalkwyk et al., 2011). Crude $\mathrm{NiSO}_{4} \cdot 6 \mathrm{H}_{2} \mathrm{O}$ crystals, containing some $\mathrm{CoSO}_{4}$ and $\mathrm{FeSO}_{4}$, serve as the outlet stream of $\mathrm{Ni}$ and $\mathrm{S}$ from the Lonmin BMR process. The atmospheric leach is followed by a 2 step pressure leach to bring $\mathrm{Cu}$ sulphides, primarily covellite $(\mathrm{CuS})$, chalcocite $\left(\mathrm{Cu}_{2} \mathrm{~S}\right)$ and cuprite $\left(\mathrm{Cu}_{2} \mathrm{O}\right)$ into solution (Dorfling et al., 2011). The residue product from the final pressure leach contains between $48 \%$ and $50 \%$ PGM material. This residue is then processed using a high pressure caustic leach to remove $\mathrm{Se}, \mathrm{Te}$, Os and As from the residue and finally through a formic acid leach to reduce and dissolve complex Fe and $\mathrm{Ni}$ oxides before being dried and dispatched to the PMR. During the pyrometallurgical test work it became evident that the need for the high pressure caustic and formic acid leach would be eliminated, as the impurities that they are meant to remove would be controlled by the pyrometallurgical process itself. For this reason, the bulk of the test work was done on residue from the high pressure $\mathrm{Cu}$ leach that contains around 50\% PGM and this paper will describe the behaviour of this material (referred to as third stage leach residue). By removing the caustic and formic leaching stages, the BMR process would be simplified and effluent generation, reagent cost and PGM losses could be reduced.

\section{METHODOLOGY}

This section will briefly describe the analytical methods used, Thermodynamic equilibrium modelling that was conducted with FactSage ${ }^{\circledR}$ and the different roasting test work campaigns.

\section{Analysis}

\section{MLA/SEM EDS to determine mineral phase composition and associations}

The samples were analysed using a Quanta 600 Scanning-electron Microscope (SEM), fitted with Energy Dispersive Spectroscopy (EDS) detectors. The mineral / phase quantification was carried out by the Mineral Liberation Analyser (MLA ${ }^{\circledR}$ ) software, to determine the mineral speciation of PGMs and associations with gangue components. The X-Ray Back-Scatter Electron (XBSE) technique was used in conjunction with MLA to determine the bulk mineralogy of the samples. This technique uses back-scattered electron (BSE) images to define phase boundaries and X-ray spectra to identify the mineralogy of each phase. 


\section{XRD bulk mineral phase quantification}

X-Ray Diffraction (XRD) analyses were done on the first set of roasting tests in an effort to understand the mineral phase changes that occur at different temperatures. Rietveld refinement software (Kleeberg et. al., 2002) was used for the modal analysis of the minerals. A PANalytical $\mathrm{X}^{\prime}$ Pert Pro powder diffractometer with $\mathrm{X}^{\prime} \mathrm{C}$ elerator detector and variable divergence- and receiving slits with Fe filtered $\mathrm{Co}-\mathrm{K} \alpha$ radiation was used for data collection. Phases were identified using X'Pert Highscore plus software.

\section{Chemical analyses}

A suite of analytical methods were used to determine different elemental abundances in the samples. These are summarized below:

- Inductively Coupled Plasma - Optical Emission Spectrometry (ICP-OES) for Pt, Pd, Au, Rh, $\mathrm{Ru}, \mathrm{Ir}, \mathrm{Ag}, \mathrm{Al}, \mathrm{Co}, \mathrm{Cr}, \mathrm{Cu}, \mathrm{Fe}, \mathrm{Mg}, \mathrm{Mn}, \mathrm{Pb}$ and $\mathrm{Zn}$.

- Inductively Coupled Plasma - Mass Spectrometry (ICP-MS) for all low level determinations of the toxic elements (As, Se, Te, Sb, Sn, and $\mathrm{Bi}$ ). Initial solid samples were prepared by either acid digestion or fusion (dependant on concentration). Os was also determined with ICP-MS.

- LECO CS200 C/S analyser was used to determine total S content.

- XRF was used for the full set of chemical element analyses. The XRF analyses proved to be an accurate indication of elemental removal efficiencies across the roasting step.

\section{Thermo-Gravimetric analyses}

Thermo-Gravimetric Analysis (TGA) and Differential Thermal Analyses (DTA) were performed on the material to understand the thermal behaviour and mass loss of the material. The sample was analysed with a Mettler Toledo 851STARe simultaneous DTA/TGA analyser.

\section{Thermodynamic Equilibrium Modelling}

Modelling of the roasting process was performed with FactSage ${ }^{\circledR}$ modelling software, version 6.2 (Bale, et.al, 2001). The modelling pointed to the temperature range and gaseous atmosphere that would be necessary to remove some of the volatile components. Modelling predictions were compared with actual experimental results to validate the databases, or to understand the limitations of applying equilibrium modelling to the studied system.

According to both the SGTE and SGNoble databases, the only solid solution phase that formed was the Face Centred Cubic (FCC) phase. Neither the FToxid or the FACT Spinel databases predicted any PGMs or volatile components ( $\mathrm{Os}, \mathrm{As}, \mathrm{Se}, \mathrm{Te}, \mathrm{Ag}$ ) to enter the spinel phase in the temperature range studied. For this reason only the ideal gas phase, pure solids phase and the SGNoble FCC solid solution phase were activated during the modelling runs.

A comparison was done between the SGTE and SGNoble databases with regards to their prediction of the FCC solid solution phase. This comparison was done with the "Normal" calculation method in Factsage with excess oxygen available in the system to ensure oxidation (140g air allowed per $100 \mathrm{~g}$ third stage residue). The results from this comparison are shown in Table 1. The SGNoble database was optimized for most of the binary element combinations below, while the SGTE database has limited data on the PGMs. A decision was taken to use the SGNoble database for modelling as an understanding of the PGM behaviour was of first importance. It must be highlighted that $\mathrm{Cu}$ shows the biggest deviation between the two databases, with the SGNoble databases showing almost 
complete dissolution of $\mathrm{Cu}$ into the $\mathrm{FCC}$ phase above $850^{\circ} \mathrm{C}$. However, actual experimental results did not reveal $\mathrm{Cu}$ in the FCC solid solution phase.

Table 1: Modelling result of the weight percentage reporting to the FCC solid solution phase with the SGNoble and SGTE databasis activated respectively ("Normal" calculation option at $140 \mathrm{~g}$ air per $100 \mathrm{~g}$ third stage residue feed).

\begin{tabular}{|c|c|c|c|c|c|c|c|c|c|c|}
\hline & Databasis & $\mathbf{6 0 0}^{\circ} \mathrm{C}$ & $\mathbf{6 5 0}^{\circ} \mathrm{C}$ & $\mathbf{7 0 0}^{\circ} \mathrm{C}$ & $\mathbf{7 5 0}^{\circ} \mathrm{C}$ & $\mathbf{8 0 0}^{\circ} \mathrm{C}$ & $\mathbf{8 5 0}^{\circ} \mathrm{C}$ & $\mathbf{9 0 0}^{\circ} \mathrm{C}$ & $\mathbf{9 5 0}^{\circ} \mathrm{C}$ & $\mathbf{1 0 0 0}^{\circ} \mathrm{C}$ \\
\hline \multirow{2}{*}{ Ir } & SGNoble & $0 \%$ & $0 \%$ & $0 \%$ & $1 \%$ & $3 \%$ & $8 \%$ & $25 \%$ & $85 \%$ & $99 \%$ \\
\cline { 2 - 12 } & SGTE & $0 \%$ & $0 \%$ & $1 \%$ & $7 \%$ & $26 \%$ & $91 \%$ & $100 \%$ & $100 \%$ & $100 \%$ \\
\hline \multirow{2}{*}{ Ag } & SGNoble & $1 \%$ & $3 \%$ & $13 \%$ & $100 \%$ & $100 \%$ & $100 \%$ & $100 \%$ & $100 \%$ & $100 \%$ \\
\cline { 2 - 11 } & SGTE & $10 \%$ & $29 \%$ & $94 \%$ & $100 \%$ & $100 \%$ & $100 \%$ & $100 \%$ & $100 \%$ & $100 \%$ \\
\hline \multirow{2}{*}{ Pd } & SGNoble & $1 \%$ & $6 \%$ & $29 \%$ & $100 \%$ & $100 \%$ & $100 \%$ & $100 \%$ & $100 \%$ & $100 \%$ \\
\cline { 2 - 11 } & SGTE & $3 \%$ & $11 \%$ & $51 \%$ & $100 \%$ & $100 \%$ & $100 \%$ & $100 \%$ & $100 \%$ & $100 \%$ \\
\hline \multirow{2}{*}{ Rh } & SGNoble & $0 \%$ & $0 \%$ & $1 \%$ & $2 \%$ & $6 \%$ & $11 \%$ & $27 \%$ & $49 \%$ & $67 \%$ \\
\cline { 2 - 11 } & SGTE & $0 \%$ & $0 \%$ & $1 \%$ & $3 \%$ & $8 \%$ & $22 \%$ & $58 \%$ & $100 \%$ & $100 \%$ \\
\hline \multirow{2}{*}{ Ru } & SGNoble & $0 \%$ & $0 \%$ & $0 \%$ & $0 \%$ & $0 \%$ & $0 \%$ & $0 \%$ & $0 \%$ & $0 \%$ \\
\cline { 2 - 11 } & SGTE & $0 \%$ & $0 \%$ & $0 \%$ & $0 \%$ & $0 \%$ & $0 \%$ & $0 \%$ & $0 \%$ & $0 \%$ \\
\hline \multirow{2}{*}{ Cu } & SGNoble & $0 \%$ & $4 \%$ & $20 \%$ & $32 \%$ & $38 \%$ & $80 \%$ & $100 \%$ & $100 \%$ & $100 \%$ \\
\cline { 2 - 11 } & SGTE & $0 \%$ & $0 \%$ & $0 \%$ & $1 \%$ & $1 \%$ & $3 \%$ & $6 \%$ & $13 \%$ & $24 \%$ \\
\hline
\end{tabular}

A comparison was also done between the "Normal" calculation option and the "Open" calculation option in FactSage. The "Normal" system evaluates set inputs into a system and then calculates equilibrium. The "Open" system evaluates equilibrium in steps; in each step the final equilibrium from the previous step is seen as the feed, while additional air is allowed into the system and the gas atmosphere from the previous step is removed. Since gas was continuous added and removed from the roasting test work performed, the "Open" method might be more appropriate from a modelling perspective. In both calculation methods a total of $140 \mathrm{~g}$ of air was allowed per $100 \mathrm{~g}$ of third stage leach residue. In the "Open" method, the air was added in steps of $10 \mathrm{~g}$ for 14 steps. Table 2 below shows a comparison of the deportment to the gas phase (overall deportment) and the FCC solid solution phase for both the "Normal" and "Open" systems.

Table 2: Comparison of the overall deportment to the gas phase and FCC solid solution phase between the "Normal" and "Open" calculation method in FactSage.

\begin{tabular}{|c|c|c|c|c|c|c|c|c|c|c|c|}
\hline Element & Phase & System & $600^{\circ} \mathrm{C}$ & $650^{\circ} \mathrm{C}$ & $7^{700}{ }^{\circ} \mathrm{C}$ & $7^{750}{ }^{\circ} \mathrm{C}$ & $800^{\circ} \mathrm{C}$ & $850^{\circ} \mathrm{C}$ & $900^{\circ} \mathrm{C}$ & $950^{\circ} \mathrm{C}$ & $1000^{\circ} \mathrm{C}$ \\
\hline \multirow{2}{*}{$\mathbf{P b}$} & \multirow{2}{*}{ Gas } & Normal & $0 \%$ & $0 \%$ & $0 \%$ & $0 \%$ & $0 \%$ & $0 \%$ & $0 \%$ & $0 \%$ & $4 \%$ \\
\hline & & Open & $0 \%$ & $0 \%$ & $0 \%$ & $2 \%$ & $6 \%$ & $17 \%$ & $38 \%$ & $73 \%$ & $99 \%$ \\
\hline \multirow{2}{*}{$\mathbf{S}$} & \multirow{2}{*}{ Gas } & Normal & $28 \%$ & $43 \%$ & $59 \%$ & $70 \%$ & $74 \%$ & $89 \%$ & $91 \%$ & $91 \%$ & $93 \%$ \\
\hline & & Open & $90 \%$ & $91 \%$ & $95 \%$ & $97 \%$ & $98 \%$ & $100 \%$ & $100 \%$ & $100 \%$ & $100 \%$ \\
\hline \multirow{2}{*}{ As } & \multirow{2}{*}{ Gas } & Normal & $9 \%$ & $100 \%$ & $100 \%$ & $100 \%$ & $100 \%$ & $100 \%$ & $100 \%$ & $100 \%$ & $94 \%$ \\
\hline & & Open & $100 \%$ & $99 \%$ & $94 \%$ & $94 \%$ & $94 \%$ & $94 \%$ & $94 \%$ & $100 \%$ & $100 \%$ \\
\hline \multirow{2}{*}{$\mathrm{Cu}$} & \multirow{2}{*}{ FCC } & Normal & $0 \%$ & $4 \%$ & $20 \%$ & $32 \%$ & $38 \%$ & $80 \%$ & $100 \%$ & $100 \%$ & $100 \%$ \\
\hline & & Open & $7 \%$ & $12 \%$ & $22 \%$ & $38 \%$ & $48 \%$ & $67 \%$ & $89 \%$ & $100 \%$ & $100 \%$ \\
\hline \multirow{2}{*}{$\mathbf{R h}$} & \multirow{2}{*}{ FCC } & Normal & $0 \%$ & $0 \%$ & $1 \%$ & $2 \%$ & $6 \%$ & $11 \%$ & $27 \%$ & $49 \%$ & $67 \%$ \\
\hline & & Open & $0 \%$ & $0 \%$ & $0 \%$ & $1 \%$ & $3 \%$ & $8 \%$ & $17 \%$ & $40 \%$ & $55 \%$ \\
\hline
\end{tabular}

The results from Table 2 will be discussed in more detail under the relevant Discusion sections. In summary, the main difference between the two methods is related to the lower oxidation potential in the "Open" system when equilibrium is calculated in the first steps with low air addition. Due to 
incomplete oxidation of most elements, $\mathrm{Pb}$ is lost in volatile species like $\mathrm{PbSe}, \mathrm{PbTe}$ and $\mathrm{PbS}$, while $\mathrm{S}$ is lost in volatile species like $\mathrm{SO}_{2}$. As will be explained later, in the case of $\mathrm{S}$, the "Open" system favourably compares to actual experimental results, when compared to the "Normal" system where complete oxidation occurs and stable sulphates form. However, in the case of $\mathrm{Pb}$ where the actual experiments did not show any $\mathrm{Pb}$ loss to the gas phase, the formation of the volatile $\mathrm{Pb}$ species like $\mathrm{PbTe}$ and $\mathrm{PbSe}$ probably do not happen, as Se and Te potentially oxidize during the heating cycle of the furnace.

The "Open" system better models the elemental deportment to the FCC solid solution phase by being closer to actual experiments results. FactSage modelling results from the "Open" system were used to interpret actual results in the Discussion section, except in the case of $\mathrm{Pb}$ where the "Normal" system better describes the measured results.

\section{Roasting}

Based on the Thermodynamic modelling and the Thermo-Gravimetric results, a first round of stationary bed roasting test work was done in a simple muffle furnace under normal atmospheric pressure and oxygen partial pressure conditions using $30 \mathrm{~g}$ of material for each test. The roasting temperature was varied between $600^{\circ} \mathrm{C}$ and $1000^{\circ} \mathrm{C}$. From this work it became clear that most of the elements behaved according to the thermodynamic equilibrium conditions predicted by FactSage, but specifically Te, As and Os failed to be extracted to the extent predicted, probably due to kinetic and mass transfer limitations.

A research campaign using a circulating fluidized bed was used for roasting tests on the third stage leach material. Here the samples were roasted in a vertical type fluidized bed reactor and again in a muffle furnace. The tests were performed with $80 \mathrm{~g}$ of material per test and the experimental conditions varied from oxygen enriched ( $40 \%$ volume basis oxygen) conditions, through inert gas compositions $\left(\mathrm{N}_{2}\right)$ to reducing environments $\left(20 \% \mathrm{CO}\right.$ and $80 \% \mathrm{~N}_{2}$ volume basis gas). Combinations of gas atmospheres (for instance oxidative following reductive and vice versa) were also tested. The tests campaign had the following objectives:

- Optimise Te, As and Os removal

- Compare different solid-gas contacting configurations, such as fluid-bed roasting versus stationary or moving bed roasting.

\section{PGM CONCENTRATE CHARACTERIZATION}

This section will discuss the general PGM concentrate characterization as well as the basic behaviour when the material is subjected to increased temperature. The following section will discuss the thermal speciation change and removal efficiencies in detail.

\section{Chemical Composition}

A typical composition of the third stage leach residue is provided in Table 3 below. The PGM content is $48.5 \%$. 
Table 3: Typical chemical composition of Lonmin BMR third stage residue, expressed as species that were used for thermodynamic modelling.

\begin{tabular}{|c|c|c|c|c|c|c|c|c|c|c|c|c|}
\hline Species & $\mathbf{P t}$ & $\mathbf{P d}$ & $\mathbf{A u}$ & $\mathbf{R h}$ & $\mathbf{R u}$ & $\mathbf{I r}$ & $\mathbf{6 E}$ & $\mathbf{S i O}_{2}$ & $\mathrm{Al}_{2} \mathbf{O}_{3}$ & $\mathbf{C a O}$ & $\mathbf{C r}_{2} \mathbf{O}_{3}$ & $\mathbf{M g O}$ \\
\hline Weight \% & 24.5 & 11.7 & 0.6 & 4.0 & 6.2 & 1.5 & 48.5 & 4.0 & 0.5 & 0.1 & 0.4 & 0.5 \\
\hline
\end{tabular}

\begin{tabular}{|c|c|c|c|c|c|c|c|c|c|c|c|c|}
\hline Species & $\mathbf{N i O}$ & $\mathbf{C u S}$ & $\mathrm{Co}_{\mathbf{3}} \mathbf{O}_{\mathbf{4}}$ & $\mathrm{Fe}_{3} \mathbf{O}_{\mathbf{4}}$ & $\mathbf{S e}$ & $\mathbf{T e}$ & $\mathbf{A s}$ & $\mathbf{P b S O}_{\mathbf{4}}$ & $\mathbf{S}$ & $\mathbf{O s}$ & Ag & Total \\
\hline Weight \% & 3.7 & 6.1 & 0.1 & 6.7 & 3.4 & 0.5 & 2.0 & 6.1 & 5.6 & 4.6 & 0.7 & $\mathbf{9 3 . 5}$ \\
\hline
\end{tabular}

The chemical composition provided in Table 3 reflects the feed speciation used for FactSage modelling. Even though the oxides of $\mathrm{Ni}, \mathrm{Fe}$ and $\mathrm{Co}$ may form a range of mixed oxide spinel minerals, it does not significantly influence the thermodynamic modelling outcomes. More detailed mineralogical investigation with XRD and electron microscope equipped with EDS capabilities is provided in the following section. The ultrafine / colloidal nature of the particles in the PGM concentrate post pressure leaching, leads to particles with poor crystallinity, as indicated by the broad band of peaks in an X-Ray diffractogram.

\section{Particle size distribution}

Figure 1 reflects a typical particle size distribution of the third stage leach residue. During the process of roasting and even drying at $100^{\circ} \mathrm{C}$, the particles tend to form agglomerates that are quite stable and the particle size change according to Error! Reference source not found.. In the wet product from the filter directly after the pressure leach step, $74 \%$ of the sample weight has a particle size smaller than 10 micron (as 


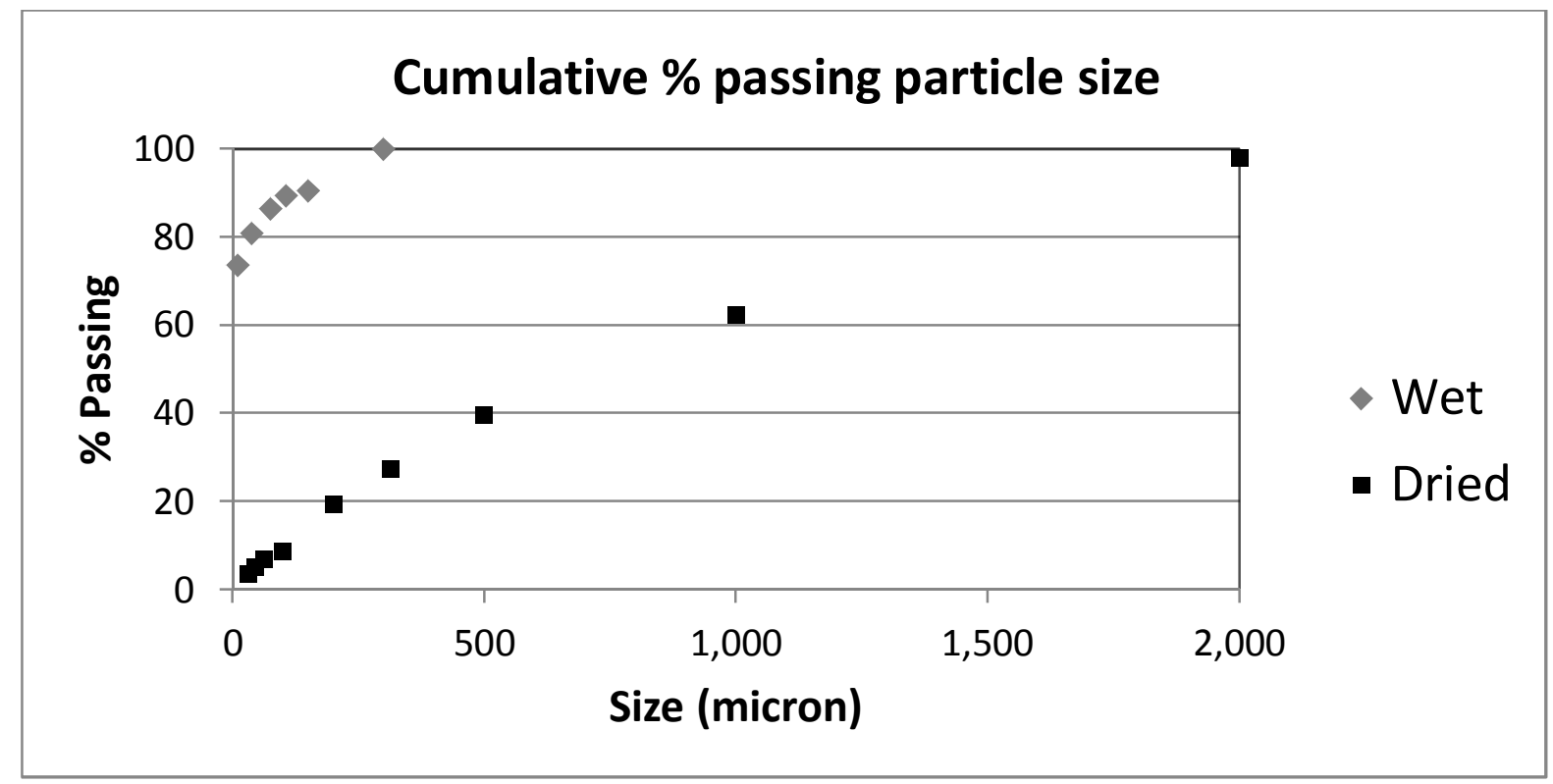

Figure 1: Cumulative percentage of particles passing a size fraction as a function of the particle size. The wet sample was measured by Malvern and the Dried sample by multiple sieve sizes.

measured by a Malvern laser diffraction particle size analyser), while the dried/ roasted product contains the bulk of the mass in the particle size range between 500 micron and 2000 micron (measured by sieve analyses). The effect that the larger particle size (agglomerates) had on the removal of volatile compounds from the matrix was found to be negligible. After roasting, fine particles were separated from coarser particles by sieving and separate elemental analyses were performed on the two samples. No measurable difference in concentration of volatiles was noted.

\section{XRD Analysis}

Samples from the stationary bed roasting test work were subjected to bulk XRD analyses. Combined XRD patterns are shown in Figure 2 below. They show the changes in the major peaks as the roasting temperature is raised. Apparent is the change in the crystallinity of the phases with increase in roasting temperature. At $25^{\circ} \mathrm{C}$ the crystallite sizes of the phases are so small that the peaks are excessively broadened. At higher temperatures the peaks are sharpened due to recrystallization and annealing. The trevorite or spinel peak intensity increases with increasing temperature. 


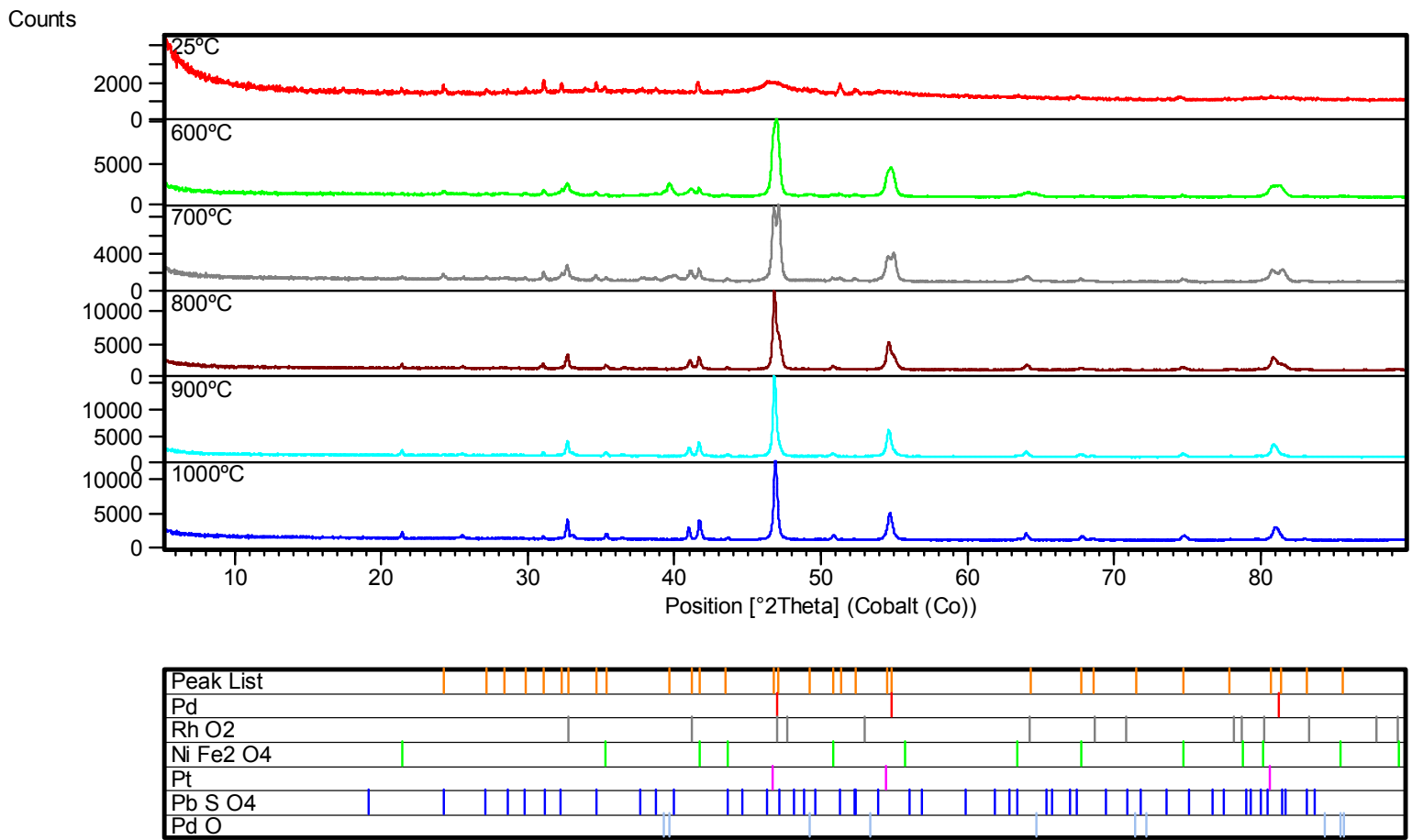

Figure 2: Comparative XRD data of the BMR 3rd stage leach residue as received and roasted at the indicated temperatures

Qualitative analysis of the $25^{\circ} \mathrm{C}$ data indicates the presence of very fine-grained platinum and palladium, together with trevorite $\left(\mathrm{NiFe}_{2} \mathrm{O}_{4}\right)$ and anglesite $\left(\mathrm{PbSO}_{4}\right)$. The metallic peaks are broadened, indicative of less crystallinity, whereas the other two phases have sharp peaks. There is only one unaccounted minor peak present.

The $600^{\circ} \mathrm{C}$ data show sharp peaks of the metals platinum and palladium, $\mathrm{RhO}_{2}$ and $\mathrm{PdO}$, as well as $\mathrm{NiFe}_{2} \mathrm{O}_{4}$ and $\mathrm{PbSO}_{4}$. All the peaks are accounted for. The pattern for $\mathrm{RuO}_{2}$ is very similar to that of $\mathrm{RhO}_{2}$ and the pattern probably represents a mixture of the two phases.

The $1000^{\circ} \mathrm{C}$ data is characterized by the disappearance of the $\mathrm{PdO}$ and anglesite $\left(\mathrm{PbSO}_{4}\right)$ phases. This will be discussed in more detail later in the paper. The XRD pattern represents the phases of platinum, palladium, $\mathrm{RuO}_{2}$, together with trevorite, quartz and cristobalite. In this case $\mathrm{RuO}_{2}$ is a better fit than $\mathrm{RhO}_{2}$, but the same argument as before is relevant, i.e that the peaks represent a mixture of the two.

Quantified results of the BMR 3rd stage leach residue roasted at different temperatures are shown in Table 4. The increase in the trevorite (or spinel) content with increase in roasting temperature can be explained only partly. This has an effect on the quantities of the other phases. This will be discussed in more detail later. The reason presented for the increase in spinel phase is the formation of a mixed spinel that is refined as trevorite. An analysis of the cell constant of trevorite is also given in Table 4. This shows a gradual increase in the a-cell parameter with a sudden decrease in the value obtained at the $1000^{\circ} \mathrm{C}$ roast. This decrease could signal the formation of a spinel with a different composition than trevorite, incorporating all the $\mathrm{Fe}, \mathrm{Ni}, \mathrm{Cu}, \mathrm{Cr}, \mathrm{Mg}, \mathrm{Al}$, and possibly even $\mathrm{Ru}$ and $\mathrm{Rh}$. 
Table 4: Quantification of phases by XRD in the BMR 3rd stage leach residue roasted at different temperatures

\begin{tabular}{|c|c|c|c|c|c|c|c|c|c|c|}
\hline & $600^{\circ} \mathrm{C}$ & & $700^{\circ} \mathrm{C}$ & & $800^{\circ} \mathrm{C}$ & & $900^{\circ} \mathrm{C}$ & & $1000^{\circ} \mathrm{C}$ & \\
\hline Phase & $\%$ & $\sigma$ & $\%$ & $\sigma$ & $\%$ & $\sigma$ & $\%$ & $\Sigma$ & $\%$ & $\sigma$ \\
\hline Anglesite $\left(\mathrm{PbSO}_{4}\right)$ & 4.7 & 0.2 & 5.3 & 0.2 & 0.0 & 0.0 & 0.0 & 0.0 & 0.0 & 0.0 \\
\hline Platinum & 18.5 & 0.3 & 20.7 & 0.2 & 28.9 & 0.2 & 34.1 & 0.3 & 21.2 & 0.6 \\
\hline Palladium & 38.3 & 0.4 & 33.4 & 0.3 & 23.9 & 0.3 & 7.2 & 0.4 & 15.6 & 0.8 \\
\hline $\mathrm{RhO}_{2} / \mathrm{RuO}_{2}$ & 17.9 & 0.3 & 14.8 & 0.2 & 15.3 & 0.2 & 15.7 & 0.2 & 13.6 & 0.2 \\
\hline PdO & 10.0 & 0.2 & 6.7 & 0.2 & 0.0 & 0.0 & 0.0 & 0.0 & 0.0 & 0.0 \\
\hline Quartz & 0.4 & 0.1 & 0.5 & 0.1 & 1.1 & 0.2 & 0.9 & 0.2 & 1.1 & 0.2 \\
\hline Trevorite/ Spinel & 10.2 & 0.3 & 18.5 & 0.3 & 30.8 & 0.3 & 34.8 & 0.4 & 38.5 & 0.6 \\
\hline Cristobalite & 0.0 & 0.0 & 0.0 & 0.0 & 0.0 & 0.0 & 7.5 & 0.6 & 10.0 & 0.5 \\
\hline $\begin{array}{c}\text { Trevorite a-cell } \\
\text { parameter }\end{array}$ & 8.3456 & $\AA$ & 8.3458 & $\AA$ & 8.3477 & $\AA$ & 8.348 & $\AA$ & 8.3404 & $\AA$ \\
\hline
\end{tabular}

\section{SEM Analysis with EDS on feed sample}

Feed and roasted samples were analysed using a Quanta 600 Scanning Electron Microscope (SEM) equipped with Energy Dispersive Spectroscopy (EDS) and the Mineral Liberation Analyser (MLA) to determine the mineral speciation and abundance. To interpret the behaviour of volatile elements from the matrix, an understanding of the minerals at grain level is necessary. However, it became clear that the residue from the pressure leach in the BMR is extremely fine grained and amorphous, resulting in varying compositions which could not be assigned stoichiometric compositions. The main findings from the SEM MLA work will be summarized below.

\section{SEM characterization of third stage leach residue feed material}

The bulk of the third stage leach residue sample consisted of oxidised particles composed of Pt-Pd$\mathrm{Rh}-\mathrm{Ru}-\mathrm{Se}-\mathrm{As}-\mathrm{S}-\mathrm{O}$, with various other PtPd phases making up the remaining sample. 8\% (surface area percentage) was present as silicates. The material tended to be porous particles, containing inclusions consisting of trevorite $\left(\mathrm{NiFe}_{2} \mathrm{O}_{4}\right)$ and other spinel minerals, villamaninite of varying compositions $\left((\mathrm{Cu}, \mathrm{Ni}, \mathrm{Co}, \mathrm{Fe}) \mathrm{S}_{2}\right)$ and silicate gangue (feldspar type). These may have provided nuclei for the growth of the Pt-Pd-Rh-Ru-Se-As-S-O phases. At higher magnification brighter phases, enriched in $\mathrm{Pt}, \mathrm{Pd}, \mathrm{Rh}, \mathrm{Ru}$ and in some cases Os were observed, with most of the particles in the micron or submicron level. In some cases, PGE enriched phases appeared to be growing on the surfaces of the silicate gangue and in other places the PGE enriched phases could have been secondary growth from the Pt-Pd-Rh-Ru-Se-As-S-O matrix.

The modal abundance data for third stage leach residue is presented in Table 5. Since the densities of most of the phases are unknown, the data has been expressed as Area\%. Due to the amorphous nature and inherent variability of mineral phases, the compositions measured are approximations of the compositions of the bulk samples. Due to the small grain size of particles, interaction of adjacent particles on the electron beam spot size will contribute to variability of elemental distribution that is used to make up the phase composition by the MLA software. 
Table 5: Average modal abundance in Third stage leach residue (Area\%), as determined by MLA

\begin{tabular}{|c|c|}
\hline $\begin{array}{c}\text { Mineral abundance, as defined by MLA } \\
\text { processing with EDS elemental distribution }\end{array}$ & $\begin{array}{c}\text { Surface area } \\
\text { abundance } \\
\text { (\%) }\end{array}$ \\
\hline PGMAlloys & 0.4 \\
\hline PtPdRuSeS & 7.2 \\
\hline PtPdRuSeS2 & 0.3 \\
\hline PtPdSRuFeO & 2.2 \\
\hline PtPdRuSeSFeCrPb & 4.2 \\
\hline PtPdRhRuSSeSi & 6.9 \\
\hline PtPdRuRhSeAsSO & 4.1 \\
\hline PtPdRhRuSeAsSO & 48.1 \\
\hline PtRuPdSe_SiPbCO & 2 \\
\hline PtPdRuAsSeSO & 9.3 \\
\hline PdCuTeSe_RuNiSO & 0.1 \\
\hline OsPtPdSSe_CO & 0.8 \\
\hline NiS_Fe & 0.7 \\
\hline Pyrite & 0.4 \\
\hline Quartz & 1.6 \\
\hline Other silicates & 6.6 \\
\hline Trevorite & 3.9 \\
\hline Other & 1.4 \\
\hline Total & 100 \\
\hline & \\
\hline & \\
\hline
\end{tabular}

Figure 3 shows a micrograph of the third stage leach residue and illustrates the fineness of grains contained in the larger particles, as well as the intermixed and varying nature of the residue. Figure 3 shows a magnified view of one of the agglomerate particles that contain the PtPdRhRuSeAsS phases together with small grain inclusions. Some grain inclusions are visible at this magnification. Grain M (PtPdRuSeS) could be secondary nucleation and growth within the matrix. Grain $\mathrm{J}$ is a chromite type grain $\left(\mathrm{FeCr}_{2} \mathrm{O}_{4}\right)$. Grain $\mathrm{K}$ is a type of feldspar (alumina silicate) inclusion. Grain L (OsPtPdSSe_CO) shows an enrichment in Os (about 20 weight \% content) and some traces of $\mathrm{C}$, which cannot be explained. The point indicated as I is enriched in $\mathrm{Pb}, \mathrm{Se}$ and $\mathrm{S}$ from the rest of the matrix. 


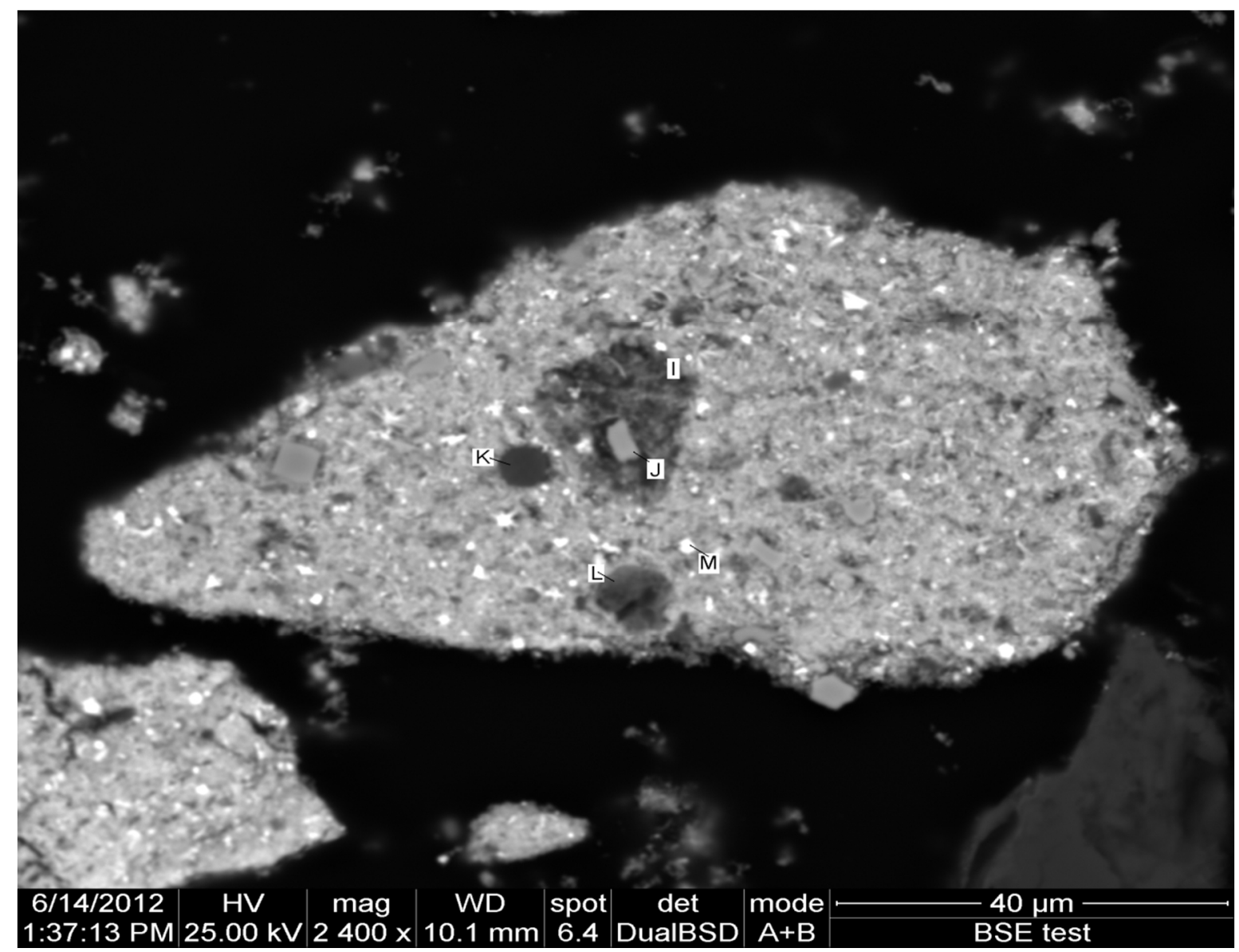

Figure 3: Photo micrograph of a particle from the third stage leach residue. Some single grains are marked and their basic composition is provided.

\section{SEM characterization of roasted product}

Third stage leach residue that was roasted at $900^{\circ} \mathrm{C}$ in air for 4 hours in a fluidized bed showed clear increase in crystallinity from the feed product. Figure 4 shows a micrograph taken with the SEM. The presence of a bright alloy phase could be noticed in all the samples, indicated by point $\mathrm{E}$ in Figure 4 . This alloy phase consist almost exclusively out of $\mathrm{Pt}$ and $\mathrm{Pd}$, with between $3 \%$ and $5 \% \mathrm{Rh}$ also measured. Encapsulated within the bright alloy phase, is very often a lighter phase, indicated by point $\mathrm{D}$ in Figure 4. This lighter phase most probably grew out of the PGM phase and is enriched in Ir, Ru, $\mathrm{Rh}$. This secondary phase contains oxygen and small amounts of $\mathrm{Fe}$ and $\mathrm{Cu}$. By far the majority of the PGM content in the sample was confined to the two phases described by point $\mathrm{D}$ and $\mathrm{E}$.

Point $\mathrm{C}$ indicates a light grey phase that is present between the brighter alloy phases. The composition of this phase is not consistent, but it is mostly an oxidized $\mathrm{As}, \mathrm{Pb}, \mathrm{Ni}, \mathrm{Cu}, \mathrm{Fe}$ phase. Trace amounts of $\mathrm{Te}, \mathrm{Os}, \mathrm{Ag}, \mathrm{Ru}$ and $\mathrm{Pt}$ was also found in the phase. The alloy phases (Points D and E) probably grew from the amorphous mixture and left behind the remaining oxide phase shown in Point $\mathrm{C}$, leaving it mostly devoid of $\mathrm{Pt}, \mathrm{Pd}, \mathrm{Ru}, \mathrm{Rh}$ and Ir.

Grain $\mathrm{A}$ is a $\mathrm{Fe}$, Ni oxide (trevorite) and this grain is surrounded by a light grey matrix shown as Point B. This light grey phase could be seen surrounding most mineral inclusions like quarts, trevorite, chromite, bronzite, etc. The light grey phase shown in Point $\mathrm{B}$ is also a varying oxidized $\mathrm{As}, \mathrm{Pb}, \mathrm{Ni}$, $\mathrm{Cu}, \mathrm{Fe}$ phase, similar to the phase described by Point $\mathrm{C}$. 
The remaining $\mathrm{Te}$ in the sample shows some association with $\mathrm{Cu}$, as some areas was found to be simultaneously enriched in $\mathrm{Te}$ and $\mathrm{Cu}$.

Grain $\mathrm{F}$ is large quartz inclusion and it originates from the silica that was added to the roast to stabilize the fluid bed.

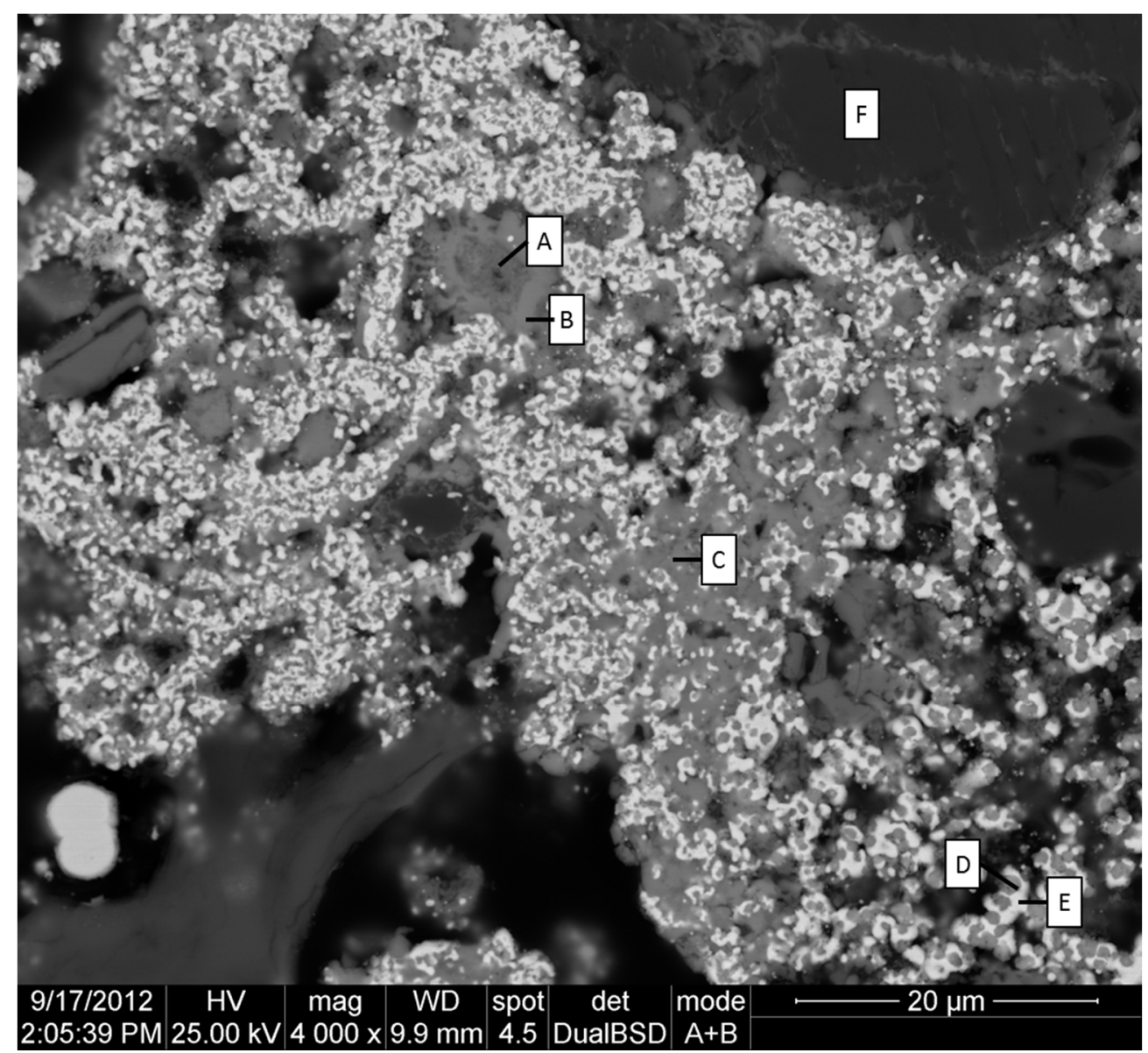

Figure 4: Photo micrograph of a particle from the roasted third stage leach residue. Some single grains are marked and their basic composition is provided.

\section{DTA/TGA/ DSC Analysis}

Figure 5 show the TGA/ DTA/ SDTA curves on third stage leach material, with the top block of the figure representing the TGA curve, the middle section representing the DTA curve and the lower section representing the SDTA curve.

DTA compares a material as it undergoes heating relative to an inert reference. By comparing it to an inert sample, any endothermic or exothermic reactions can be measured as a function of temperature. Differential Thermal analyses (DTA) showed an endothermic range of around $400^{\circ} \mathrm{C}$ to $550^{\circ} \mathrm{C}$. No other significant reactions took place in the $600^{\circ} \mathrm{C}$ to $1000^{\circ} \mathrm{C}$ temperature range. Simultaneous Differential Thermal analyses (SDTA) is the application of TGA and DTA to the same sample at the same time.

Thermogravimetric analyses (TGA) measures the change in weight as a function of the temperature. The TGA curve shows essentially a continuous mass loss with increasing temperature, with an accelerated mass loss between $450^{\circ} \mathrm{C}$ and $550^{\circ} \mathrm{C}$. The increased mass loss and endothermic range 
between $450^{\circ} \mathrm{C}$ and $550^{\circ} \mathrm{C}$ probably corresponds to the loss of crystal water. Further heating once again shows continuous mass loss till $1200^{\circ} \mathrm{C}$ (maximum temperature of TGA test). Total mass loss is around $25 \%$ at $1000^{\circ} \mathrm{C}$ (starting from a product that was dried at $100^{\circ} \mathrm{C}$ ). Table 6 shows the actual mass loss from roasted samples at different temperatures compared very closely to the TGA curves. At higher temperatures (above $800^{\circ} \mathrm{C}$ ), the FactSage predictions on mass loss is comparable to measured values. The variation of the FactSage prediction from actual measurements at $600^{\circ} \mathrm{C}$ and $700^{\circ} \mathrm{C}$ is probably due to the kinetic effects relative to the equilibrium prediction of the FactSage results. Under equilibrium conditions FactSage predicts the full oxidation of all the PGMs (apart from $\mathrm{Pt}$ and $\mathrm{Au}$ ) and Base Metals to their respective stable oxides at $600^{\circ} \mathrm{C}$, while the XRD analyses in Table 4 confirms the presence of un-oxidized Pd. Other PGMs and the base metals probably did not oxidize to the extent predicted by FactSage.

Table 6: Mass loss comparison between TGA measurement, roasting test work measurement and FactSage prediction

\begin{tabular}{|c|c|c|c|c|c|}
\hline & $600^{\circ} \mathrm{C}$ & $700^{\circ} \mathrm{C}$ & $800^{\circ} \mathrm{C}$ & $900^{\circ} \mathrm{C}$ & $1000^{\circ} \mathrm{C}$ \\
\hline TGA measurement & $15 \%$ & $17 \%$ & $20 \%$ & $22 \%$ & $24 \%$ \\
\hline $\begin{array}{c}\text { Roasting test work } \\
\text { measurement }\end{array}$ & $19 \%$ & $22 \%$ & $24 \%$ & $24 \%$ & $25 \%$ \\
\hline FactSage predictions & $9 \%$ & $11 \%$ & $17 \%$ & $20 \%$ & $24 \%$ \\
\hline
\end{tabular}

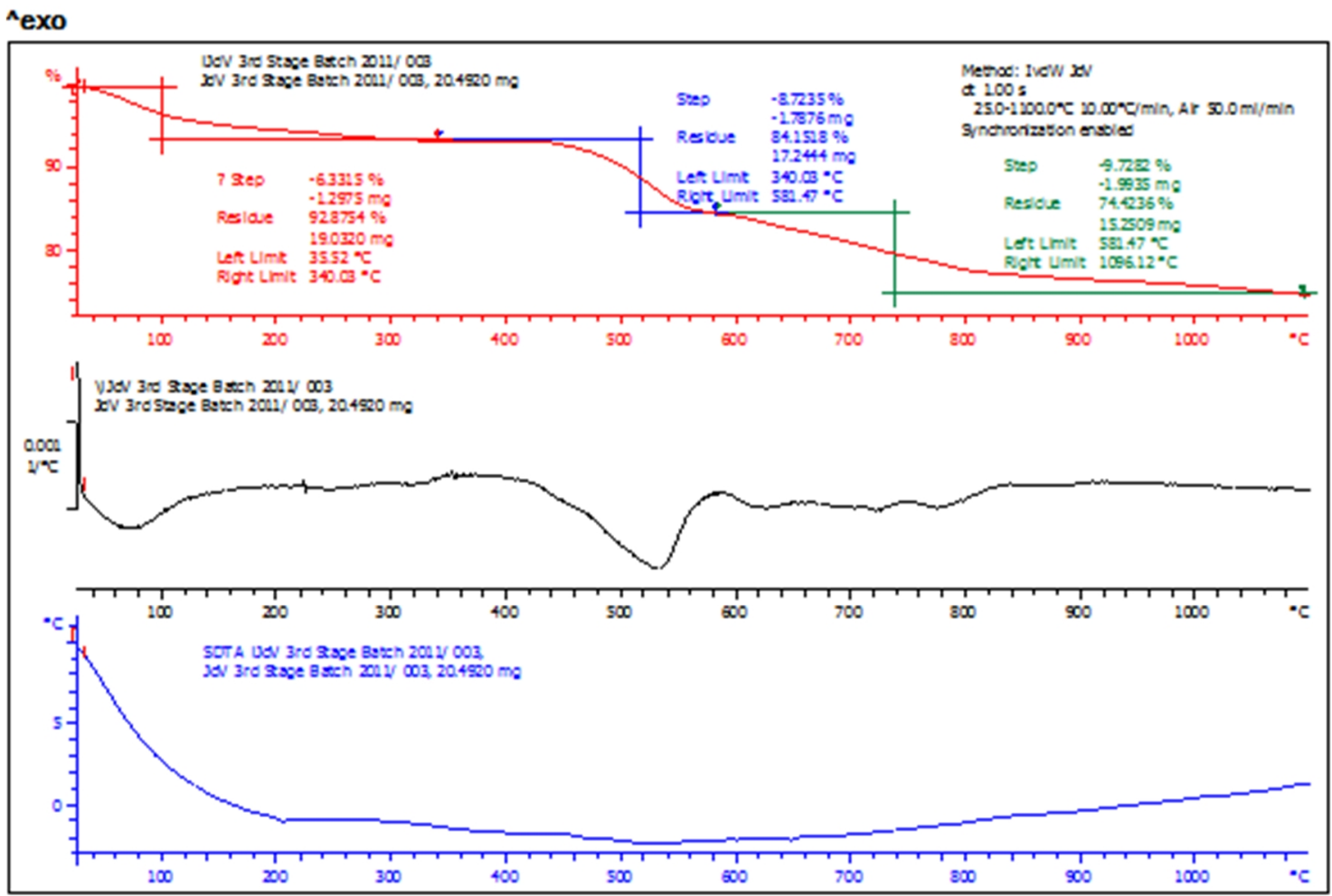

Figure 5: Combined TGA/ DTA analysis of the BMR 3rd stage leach residue . 


\section{RESULTS FROM ROASTING TEST WORK}

As already described in the experimental procedure section, two different test work campaigns were performed. The results (removal efficiencies) achieved during these test runs will be summarized below. The interpretation of the results will be done in a separate section and elements will be grouped according to logical divisions, these being PGMs, volatile components, $\mathrm{Pb}$ and stable oxides.

\section{Results of the extent of removal of elements/ compounds during the roasting trials}

Five stationary roasting tests were performed $\left(30 \mathrm{~g}\right.$ each) in a muffle furnace at $100^{\circ} \mathrm{C}$ intervals from $600^{\circ} \mathrm{C}$ to $1000^{\circ} \mathrm{C}$. A draft of air was allowed through the furnace by suction and bubbled through a water scavenger to condense and absorb soluble species. The material was left at temperature for two hours. Table 7 below contains the summary of the results for elements that can display volatile behaviour, as well as the PGMs. The results are expressed as elemental removal across the roast (removed weight of element expressed as percentage of starting weight of element).

Table 7: Percentage weight change achieved at temperature increment during the stationary bed roasting test work. Temperature of the roast increased in $100^{\circ} \mathrm{C}$ steps from $600^{\circ} \mathrm{C}$ to $1000^{\circ} \mathrm{C}$.

\begin{tabular}{|c|c|c|c|c|c|}
\hline Temperature & $600^{\circ} \mathrm{C}$ & $700^{\circ} \mathrm{C}$ & $800^{\circ} \mathrm{C}$ & $900^{\circ} \mathrm{C}$ & $1000^{\circ} \mathrm{C}$ \\
\hline Roast time & $2 \mathrm{~h}$ & $2 \mathrm{~h}$ & $2 \mathrm{~h}$ & $2 \mathrm{~h}$ & $2 \mathrm{~h}$ \\
\hline Air flow & Convection & Convection & Convection & Convection & Convection \\
\hline $\mathrm{Ru}$ & $1 \%$ & $1 \%$ & $3 \%$ & $3 \%$ & $2 \%$ \\
\hline $\mathrm{Rh}$ & $0 \%$ & $-5 \%$ & $2 \%$ & $0 \%$ & $-1 \%$ \\
\hline $\mathrm{Pd}$ & $1 \%$ & $2 \%$ & $4 \%$ & $2 \%$ & $1 \%$ \\
\hline $\mathrm{Ag}$ & $0 \%$ & $1 \%$ & $-1 \%$ & $-2 \%$ & $-5 \%$ \\
\hline $\mathrm{Ir}$ & $1 \%$ & $-2 \%$ & $3 \%$ & $2 \%$ & $0 \%$ \\
\hline $\mathrm{Pt}$ & $0 \%$ & $2 \%$ & $5 \%$ & $4 \%$ & $8 \%$ \\
\hline $\mathrm{Au}$ & $0 \%$ & $8 \%$ & $5 \%$ & $4 \%$ & $5 \%$ \\
\hline $\mathrm{Pb}$ & $2 \%$ & $-6 \%$ & $-14 \%$ & $6 \%$ & $-10 \%$ \\
\hline $\mathrm{Se}$ & $-92 \%$ & $-91 \%$ & $-94 \%$ & $-82 \%$ & $-94 \%$ \\
\hline $\mathrm{Te}$ & $-23 \%$ & $-17 \%$ & $-20 \%$ & $-28 \%$ & $-40 \%$ \\
\hline $\mathrm{As}$ & $-60 \%$ & $-64 \%$ & $-55 \%$ & $-37 \%$ & $-32 \%$ \\
\hline $\mathrm{Bi}$ & $-6 \%$ & $-9 \%$ & $2 \%$ & $8 \%$ & $4 \%$ \\
\hline $\mathrm{Total} \mathrm{S}$ & $-83 \%$ & $-95 \%$ & $-98 \%$ & $-100 \%$ & $-100 \%$ \\
\hline $\mathrm{Os}$ & $-3 \%$ & $-13 \%$ & $-33 \%$ & $-54 \%$ & $-71 \%$ \\
\hline
\end{tabular}

Sampling error and assaying errors are present where small variations (marginal increase in loss of an element followed by a subsequent mass gain) can be seen in the results of Table 7. It is clear which elements are effectively removed and are temperature responsive. The low extent of removal of Te, Os and As are noteworthy. FactSage predictions indicated a clear sensitivity of gas volume to achieve acceptable removal efficiency of especially Te.

A fluidized bed roaster was used to provide good gas/ solid contact and should better illustrate what limits of removal can be achieved by the roasting step. The stationary roasting tests showed insufficient removal of Te, Os and As, despite thermodynamic predictions. However, crucibleconcentrate interactions, slow diffusion through the stationary bed and temperature variations 
throughout the stationary bed are expected to limit the diffusion and mass transfer rates. It was postulated that improved solid-gas contact would increase the removal of these elements (Te, Os and As). Table 8 below contains a summary of the test results that were achieved. The summary is only for roast tests in oxidative environments, although a number of tests were done in inert environments (with $\mathrm{N}_{2}$ gas) and reducing environments (combination of $\mathrm{CO}$ and $\mathrm{N}_{2}$ gas) to see if there would be an improvement on As removal. This will be discussed in more detail later. The removal efficiencies were not calculated on a closed mass balance (weight in and weight out), as there were some fines carry over to the off-gas in the fluidized bed. It was rather decided to use Pt as a tie element (as Pt is inert throughout the roast and it is the most abundant element in the leach residue which can be analysed with high accuracy). Removal efficiencies were therefore calculated as the difference of the elemental ratio to Platinum for the feed and the final product.

Table 8: Percentage weight change achieved during the fluidized bed roasting test work. Gas flow was $1.2 \mathrm{Nm}^{3} / \mathrm{hr}$ for all tests reported.

\begin{tabular}{|c|c|c|c|c|c|c|}
\hline Temperature & $700{ }^{\circ} \mathrm{C}$ & $900{ }^{\circ} \mathrm{C}$ & $900{ }^{\circ} \mathrm{C}$ & $900^{\circ} \mathrm{C}$ & $900{ }^{\circ} \mathrm{C}$ & $1000^{\circ} \mathrm{C}$ \\
\hline Roast Time & $6 \mathrm{~h}$ & $60 \mathrm{~min}$ & $2 \mathrm{~h}$ & $6 \mathrm{~h}$ & $4 \mathrm{~h}$ & $4 \mathrm{~h}$ \\
\hline $\begin{array}{c}\text { Gas } \\
\text { atmosphere }\end{array}$ & Air & Air & Air & Air & $\begin{array}{c}40 \% \\
\text { Oxygen }\end{array}$ & $\begin{array}{c}40 \% \\
\text { Oxygen }\end{array}$ \\
\hline $\mathrm{Ru}$ & $2 \%$ & $10 \%$ & $7 \%$ & $2 \%$ & $5 \%$ & $3 \%$ \\
\hline $\mathrm{Rh}$ & $2 \%$ & $11 \%$ & $9 \%$ & $7 \%$ & $4 \%$ & $17 \%$ \\
\hline $\mathrm{Pd}$ & $0 \%$ & $5 \%$ & $4 \%$ & $2 \%$ & $-1 \%$ & $11 \%$ \\
\hline $\mathrm{Ag}$ & $-9 \%$ & $7 \%$ & $-10 \%$ & $-13 \%$ & $-17 \%$ & $15 \%$ \\
\hline $\mathrm{Ir}$ & $4 \%$ & $10 \%$ & $8 \%$ & $5 \%$ & $10 \%$ & $-8 \%$ \\
\hline $\mathrm{Pt}$ & $0 \%$ & $0 \%$ & $0 \%$ & $0 \%$ & $0 \%$ & $0 \%$ \\
\hline $\mathrm{Au}$ & $-4 \%$ & $-5 \%$ & $-4 \%$ & $-4 \%$ & $-9 \%$ & $0 \%$ \\
\hline $\mathrm{Pb}$ & $7 \%$ & $0 \%$ & $6 \%$ & $1 \%$ & $0 \%$ & $7 \%$ \\
\hline $\mathrm{Se}$ & $-95 \%$ & $-94 \%$ & $-95 \%$ & $-96 \%$ & $-96 \%$ & $-96 \%$ \\
\hline $\mathrm{Te}$ & $4 \%$ & $-65 \%$ & $-77 \%$ & $-77 \%$ & $-71 \%$ & $-99 \%$ \\
\hline $\mathrm{As}$ & $-42 \%$ & $-45 \%$ & $-49 \%$ & $-52 \%$ & $-36 \%$ & $-62 \%$ \\
\hline $\mathrm{Bi}$ & $2 \%$ & $20 \%$ & $15 \%$ & $10 \%$ & $4 \%$ & $24 \%$ \\
\hline $\mathrm{Total} \mathrm{S}$ & $-99 \%$ & $-100 \%$ & $-100 \%$ & $-100 \%$ & $-100 \%$ & $-100 \%$ \\
\hline $\mathrm{Os}$ & $-29 \%$ & $-22 \%$ & $-49 \%$ & $-51 \%$ & $-50 \%$ & $-48 \%$ \\
\hline
\end{tabular}

Table 9 shows a comparison between the extent of removal achieved with stationary bed roasting, fluidized bed roasting and thermodynamic equilibrium modelling. The table shows a short roasting period and a long roasting period for the stationary bed and the fluidized bed respectively. With the short roasting time, the extent of removal of the fluid bed is higher than the stationary bed. This is reflected in the results of Te removal showing a difference between $28 \%$ and $65 \%$ removal. It is clear that better amphoteric removal can be obtained in the fluid bed due to the good gas flow control and mixing in the heated chamber, which is not achievable in the stationary bed.

At 6 hour roasting times in the stationary bed, removal efficiencies of Se, Te and As are comparable to the fluid bed roasting at 1 hour. Comparing the fluid bed roasting time of 6 hours with 1 hour , Te removal improves from $65 \%$ to $77 \%$ and As removal from $45 \%$ to $52 \%$. The marginal increase of removal achieved on volatile elements (especially Te, As and Os) at the 6 hour residence time might point to these elements being present in stable compounds that do not show volatile behaviour similar 
to the pure oxides. The quantitative removal of $\mathrm{Se}$ and $\mathrm{S}$ and the presence of $\mathrm{Ru}, \mathrm{Rh}$ and $\mathrm{Ir}$ oxides occluded by alloy (from Figure 4) points that oxidation has progressed deep into the agglomerates. This supports the hypothesis that stable oxides are limiting the volatile behaviour of the amphoteric elements, rather than a mass transfer limitation of oxygen during long residence times in a fluid bed reactor.

In the case of Os removal, there is a clear improvement from a 60 minute residence time to a $2 \mathrm{~h}$ residence time. Residence times longer than $2 \mathrm{~h}$ all seem to show removal efficiencies in the $50 \%$ range, also indicating that Os volatile behaviour is probably not controlled by the formation of the pure oxide only.

Thermodynamic modelling with FactSage predicts a 100\% removal of Se, Te, As, Bi and Os at $900^{\circ} \mathrm{C}$. This is based on the formation of pure oxides that have very high vapour pressures at this temperature. The test work in this paper show that Te, As and Os are not forming pure oxides, but rather complex oxide phases that are more stable at the $900^{\circ} \mathrm{C}$ range.

Table 9: Comparison of percentage weight change achieved with stationary bed, fluidized bed and thermodynamic equilibrium modelling at $900^{\circ} \mathrm{C}$ in air.

\begin{tabular}{|c|c|c|c|c|c|}
\hline & $\begin{array}{c}\text { Stationary } \\
\text { bed result }\end{array}$ & $\begin{array}{c}\text { Fluid bed } \\
\text { result }\end{array}$ & $\begin{array}{c}\text { Stationary } \\
\text { bed result }\end{array}$ & $\begin{array}{c}\text { Fluid bed } \\
\text { result }\end{array}$ & $\begin{array}{c}\text { Thermodynamic } \\
\text { modelling result }\end{array}$ \\
\hline Temperature & $900{ }^{\circ} \mathrm{C}$ & $900{ }^{\circ} \mathrm{C}$ & $900{ }^{\circ} \mathrm{C}$ & $900{ }^{\circ} \mathrm{C}$ & $900{ }^{\circ} \mathrm{C}$ \\
\hline Roast Time & $2 \mathrm{~h}$ & $60 \mathrm{~min}$ & $6 \mathrm{~h}$ & $6 \mathrm{~h}$ & Equilibrium \\
\hline Gas atmosphere & Air & Air & Air & Air & Air \\
\hline$\% \mathrm{Ru}$ & $3 \%$ & $10 \%$ & $1 \%$ & $2 \%$ & $0 \%$ \\
\hline$\% \mathrm{Rh}$ & $0 \%$ & $11 \%$ & $4 \%$ & $7 \%$ & $0 \%$ \\
\hline$\% \mathrm{Pd}$ & $2 \%$ & $5 \%$ & $1 \%$ & $2 \%$ & $0 \%$ \\
\hline$\% \mathrm{Ag}$ & $-2 \%$ & $7 \%$ & $-16 \%$ & $-13 \%$ & $0 \%$ \\
\hline$\% \mathrm{Ir}$ & $2 \%$ & $10 \%$ & $7 \%$ & $5 \%$ & $0 \%$ \\
\hline$\% \mathrm{Pt}$ & $4 \%$ & $0 \%$ & $0 \%$ & $0 \%$ & $0 \%$ \\
\hline$\% \mathrm{Au}$ & $4 \%$ & $-5 \%$ & $2 \%$ & $-4 \%$ & $0 \%$ \\
\hline$\% \mathrm{~Pb}$ & $6 \%$ & $0 \%$ & $2 \%$ & $1 \%$ & $0 \%$ \\
\hline$\% \mathrm{Se}$ & $-82 \%$ & $-94 \%$ & $-96 \%$ & $-96 \%$ & $-100 \%$ \\
\hline$\% \mathrm{Te}$ & $-28 \%$ & $-65 \%$ & $-59 \%$ & $-77 \%$ & $-100 \%$ \\
\hline$\% \mathrm{As}$ & $-37 \%$ & $-45 \%$ & $-45 \%$ & $-52 \%$ & $-100 \%$ \\
\hline$\% \mathrm{Bi}$ & $8 \%$ & $20 \%$ & $2 \%$ & $10 \%$ & $-100 \%$ \\
\hline$\% \mathrm{Total} \mathrm{S}$ & $-100 \%$ & $-100 \%$ & $-100 \%$ & $-100 \%$ & $-100 \%$ \\
\hline$\% \mathrm{Os}$ & $-54 \%$ & $-22 \%$ & $-59 \%$ & $-51 \%$ & $-100 \%$ \\
\hline
\end{tabular}

\section{DISCUSSION OF ROASTING TEST WORK RESULTS}

\section{Discussion of PGM behaviour over the $600^{\circ} \mathrm{C}$ to $1000^{\circ} \mathrm{C}$ temperature range}

Some of the PGMs $(\mathrm{Ru}, \mathrm{Rh}, \mathrm{Pd}, \mathrm{Ir})$ have the tendency to oxidize at the lower temperatures investigated in this study $\left(600^{\circ} \mathrm{C}\right.$ to $\left.800^{\circ} \mathrm{C}\right)$, while some can retain their oxide state to the $1000^{\circ} \mathrm{C}$ roasting temperature $(\mathrm{Rh}$ and $\mathrm{Ru})$. Pt and $\mathrm{Au}$ do not oxidize in the roasting temperature range. 
However, due to the noble nature of PGMs, they all dissociate to their metallic form as temperatures continue to increase. At higher temperatures $\left(900^{\circ} \mathrm{C}\right.$ to $\left.1700^{\circ} \mathrm{C}\right)$, the vapour pressure of most PGM oxides become measurable and this may translate in $\mathrm{Ru}$ and $\mathrm{Ir}$ losses to the gas phase as oxide vapour during roasting (Jehn, H., 1984). Except for Pd, the vapour pressures of all PGM oxides are several orders of magnitude higher than their metallic states. During high temperature $\left(800^{\circ} \mathrm{C}\right.$ to $\left.1700^{\circ} \mathrm{C}\right)$ oxidation in air, $\mathrm{Rh}$ has the lowest mass loss to vapour, followed closely by Palladium and Platinum. The mass loss to vapour of Ru and Ir are much higher, whereas Os oxidizes and is lost to vapour most rapidly.

The specific behaviour of each PGM element will now be briefly discussed. The basis of the discussion is based on modelling results from FactSage (SGNoble solution databases). Where the modelling behaviour was found to differ from the experimental work, it will be highlighted.

Platinum $(\mathrm{Pt})$ and gold $(\mathrm{Au})$ do not oxidize at the lower temperatures $\left(600^{\circ} \mathrm{C}\right.$ to $\left.1000^{\circ} \mathrm{C}\right)$ in air. Their vapour pressures are so low at the roasting temperature range that no losses to the gas phase was predicted by modelling or measured in the test work. Thermodynamic modelling predicts that $\mathrm{Pt}$ and Au will always be present in the face centred cubic (FCC) solid solution phase that makes up the bulk of the solid mass. The SEM work showed the presence of a metallic FCC Pt-Pd alloy phase at $900^{\circ} \mathrm{C}$. Bulk XRD measurements in Table 4 also confirmed the presence of the metallic FCC Pt-Pd alloy phase. Au was not measured in the alloy, but this might be due to the low content $(0.6 \%)$ of $\mathrm{Au}$ in the original sample. The low Au content of the sample also caused the large recovery variance reported in the roasting test work results.

Palladium $(\mathrm{Pd})$ has the ability to oxidize in the studied temperature range of $600^{\circ} \mathrm{C}$ to $800^{\circ} \mathrm{C}$. $\mathrm{PdO}_{2}$ is stable until about $773^{\circ} \mathrm{C}$, although FactSage predicts that Pd already starts to join the FCC solid solution phase at $650^{\circ} \mathrm{C}$. Pure $\mathrm{PdO}_{2}$ can theoretically dissociate to $\mathrm{PdO}$ between $773^{\circ} \mathrm{C}$ and $804^{\circ} \mathrm{C}$, but in the complex residue this does not happen, as Pd rather joins the solid solution phase with Pt. Bulk XRD work reported in Table 4 confirms that $\mathrm{Pd}$ in the metallic form is measured across the entire temperature range of $600^{\circ} \mathrm{C}$ to $1000^{\circ} \mathrm{C}$. The XRD results in Table 4 further show the PdO phase present at $600^{\circ} \mathrm{C}$ and $700^{\circ} \mathrm{C}$, but the peak disappears at $800^{\circ} \mathrm{C}$. Since this phase stoichiometry could not be verified, no conclusion can be drawn to the oxidation state of $\mathrm{Pd}$ at the lower temperatures. SEM work on the $900^{\circ} \mathrm{C}$ sample confirmed that almost all Pt and Pd was present as a solid solution alloy. No loss to the gas phase as vapour was predicted or measured over the roasting temperature range.

Thermodynamic modelling in FactSage predicts that Iridium (Ir) fully oxidizes to $\mathrm{IrO}_{2}$ at the lower temperatures in air. In the complex residue matrix, $\mathrm{IrO}_{2}$ starts to dissociate and $\mathrm{Ir}$ joins the FCC solid solution phase between $700^{\circ} \mathrm{C}$ and $900^{\circ} \mathrm{C}$ (although most of this dissociation to Ir in the solid solution phase happens close to $900^{\circ} \mathrm{C}$ ). Pure $\mathrm{IrO}_{2}$ dissociates at about $1030^{\circ} \mathrm{C}$ and the solid solution matrix lowers the dissociation temperature by almost $150^{\circ} \mathrm{C}$. SEM analysis on the roasted sample at $900^{\circ} \mathrm{C}$ showed that oxidized $\mathrm{Ir}, \mathrm{Rh}$ and $\mathrm{Ru}$ was occluded as a separate phase from the Pt-Pd based alloy. It would appear that Ir does not dissociate to metal to join the FCC solid solution phase at $900^{\circ} \mathrm{C}$, as predicted by FactSage.

FactSage predicts small losses of $\mathrm{Ir}$ to the gas phase in the form of $\mathrm{IrO}_{3}$, with a $0.3 \%$ vapour loss predicted to the gas phase between $900^{\circ} \mathrm{C}$ and $1000^{\circ} \mathrm{C}$. The vapour losses of $\mathrm{Ir}$ happen through the further oxidation of $\mathrm{IrO}_{2}$ to $\mathrm{IrO}_{3}$ (gaseous phase). While the sensitivity of the experimental set-up does not allow measurement of Ir losses less than a couple of percent, Ir losses was measured in the single roasting test done at $1000^{\circ} \mathrm{C}$ in $40 \%$ oxygen atmosphere for a $4 \mathrm{~h}$ period (See Table 8 ). The measured 
$8 \%$ loss is questionable as neither literature nor modelling supports this, while Ru losses did not accompany the Ir loss.

Ruthenium $(\mathrm{Ru})$ fully oxidizes to $\mathrm{RuO}_{2}$ at low temperatures and remains stable as this oxide through the $1000^{\circ} \mathrm{C}$ temperature range. According to FactSage, $\mathrm{RuO}_{2}$ does not join the solid solution phase at all, but remains stable as a pure $\mathrm{RuO}_{2}$ solid. $\mathrm{Ru}$ and $\mathrm{Os}$ are the only precious metals that has a hexagonal close packed (HCP) crystal structure, while the rest (Pt, Pd, Rh, Ir and $\mathrm{Au}$ ) all have the face centered cubic (FCC) crystal structure. Despite this difference in crystal structures of the metals, Vines et. al (1941) reports that up to $68 \% \mathrm{Ru}$ (highest addition studied) will form solid solutions with $\mathrm{Pt}$ in the metallic state. The SEM work on the $900^{\circ} \mathrm{C}$ roasting sample showed that the oxidized state of $\mathrm{Ru}$ does not join the Pt Pd alloy phase, but is present as a separate solid solution phase. Although FactSage accurately modelled the presence of the Ru oxide phase, the presence of Ir and Rh oxides in this solution phase was not predicted by FactSage.

$\mathrm{RuO}_{2}\left(\right.$ as $\mathrm{RuO}_{3}$ and $\left.\mathrm{RuO}_{4}\right)$ and $\mathrm{IrO}_{2}\left(\right.$ as $\mathrm{IrO}_{3}$ ) have the highest vapour pressure of the PGM oxides (after $\mathrm{Os}$ as $\mathrm{OsO}_{4}$ ). It is exactly the opposite for the metals, with $\mathrm{Ru}$ and $\mathrm{Ir}$ having the lowest vapour pressures compared to Os in a vacuum. $\mathrm{Ru}$ losses to the gas phase can become measurable around $1000^{\circ} \mathrm{C}$, with $0.5 \%$ losses (as $\mathrm{RuO}_{3}$ and $\mathrm{RuO}_{4}$ ) predicted at thermodynamic equilibrium. As a pure $\mathrm{RuO}_{2}$ solid, $\mathrm{Ru}$ will only dissociate from oxygen at about $1470^{\circ} \mathrm{C}$. Losses of $\mathrm{Ru}$ to the vapour phase proceeds by the further oxidation of $\mathrm{RuO}_{2}$ to $\mathrm{RuO}_{3}$ and $\mathrm{RuO}_{4}$ which are both gaseous oxides only.

Thermodynamic equilibrium predicts that $\mathrm{Rh}$ is present as an oxide in the full temperature range of roasting $\left(600^{\circ} \mathrm{C}\right.$ to $\left.1000^{\circ} \mathrm{C}\right)$, albeit in different oxidation states $(4+, 3+$ and $2+$ respectively). The bulk mineralogical work in Table 4 confirms the presence of $\mathrm{Ru}$ and $\mathrm{Rh}$ oxides across the entire roasting temperature range. However, at thermodynamic equilibrium it is predicted that $\mathrm{Rh}$ will increasingly dissociate from the pure oxide form and join the solid solution phase (Pt-Pd alloy phase from the SEM study) as the temperature increases. The thermodynamic equilibrium prediction of the solution of $\mathrm{Rh}$ into the Pt-Pd solid solution phase is shown in Table 10. SEM EDS analyses on the Pt-Pd alloy (FCC solid solution) phase confirms the presence of some Rh in this phase, typically varying between $3 \%$ and 5\% weight percentage content. This translates to between a $20 \%$ and a $30 \%$ distribution of $\mathrm{Rh}$ to the FCC Pt-Pd solid solution phase. This compares very favourably with the $27.1 \%$ distribution to the metallic FCC phase prediction by FactSage at $900^{\circ} \mathrm{C}$.

Thermodynamic equilibrium does not predict any losses of $\mathrm{Rh}$ to the gas phase and no measureable losses could be seen during the experimental test work. Pure $\mathrm{RhO}_{2}$ will change oxidation state to $\mathrm{Rh}_{2} \mathrm{O}_{3}$ at about $775^{\circ} \mathrm{C}$ and $\mathrm{Rh}_{2} \mathrm{O}_{3}$ will change to $\mathrm{Rh}_{2} \mathrm{O}$ at about $950^{\circ} \mathrm{C}$. Pure $\mathrm{Rh}_{2} \mathrm{O}$ will only dissociate to $\mathrm{Rh}$ metal around $1760^{\circ} \mathrm{C}$. Despite the higher dissociation temperature (compared to $\mathrm{Ru}$ ), $\mathrm{Rh}$ tends to join solution phases (solid and liquid) easier than Ru due to the compatible FCC crystal structure. 
Table 10: FactSage (thermodynamic equilibrium) prediction of $R h$ distribution between the FCC solid solution phase and the oxide phase, as well as the stable oxidation states in the residue as a function of temperature.

\begin{tabular}{|c|c|c|c|c|c|c|c|c|c|}
\hline & $600^{\circ} \mathrm{C}$ & $650^{\circ} \mathrm{C}$ & $700^{\circ} \mathrm{C}$ & $750^{\circ} \mathrm{C}$ & $800^{\circ} \mathrm{C}$ & $850^{\circ} \mathrm{C}$ & $900^{\circ} \mathrm{C}$ & $950^{\circ} \mathrm{C}$ & $1000^{\circ} \mathrm{C}$ \\
\hline $\begin{array}{c}\% \text { Distribution of } \\
\text { Rh to FCC Pt-Pd } \\
\text { solid solution }\end{array}$ & $0.1 \%$ & $0.4 \%$ & $0.9 \%$ & $2.3 \%$ & $6.1 \%$ & $11.5 \%$ & $27.1 \%$ & $49.3 \%$ & $66.8 \%$ \\
\hline $\begin{array}{c}\% \text { Distribution of } \\
\text { Rh to pure solid } \\
\text { oxide }\end{array}$ & $99.9 \%$ & $99.6 \%$ & $99.1 \%$ & $97.7 \%$ & $93.9 \%$ & $88.5 \%$ & $72.9 \%$ & $50.7 \%$ & $33.2 \%$ \\
\hline $\begin{array}{c}\text { Dominant oxidation } \\
\text { state as pure solid } \\
\text { oxide }\end{array}$ & $\mathrm{RhO}_{2}$ & $\mathrm{RhO}_{2}$ & $\mathrm{RhO}_{2}$ & $\mathrm{Rh}_{2} \mathrm{O}_{3}$ & $\mathrm{Rh}_{2} \mathrm{O}_{3}$ & $\mathrm{Rh}_{2} \mathrm{O}_{3}$ & $\mathrm{Rh}_{2} \mathrm{O}_{3}$ & $\mathrm{Rh}_{2} \mathrm{O}$ & $\mathrm{Rh}_{2} \mathrm{O}$ \\
\hline
\end{tabular}

Oxidation of the OPMs at temperatures in the $800^{\circ} \mathrm{C}$ to $900^{\circ} \mathrm{C}$ range has been noted in the industry. This is in contrast to the PMs (Precious Metals - term used to describe the grouping of Pt, $\mathrm{Pd}$ and $\mathrm{Au}$ ) that remains present as a metal in an oxidizing environment at the same temperatures. Oxidized OPMs have a tendency to be poorly soluble in aqua regia (mixture of nitric and hydrochloric acid) and also in a $\mathrm{HCl} / \mathrm{Cl}_{2}$ environment, though to a lesser degree. Historically, this difference between the behaviour of OPMs and PMs after roasting has been used industrially as a crude method to achieve separation between PMs and OPMs, thereby simplifying and optimizing the respective refining circuits for each.

\section{Discussion of volatile behaviour of compounds in the $600^{\circ} \mathrm{C}$ to $1000^{\circ} \mathrm{C}$ temperature range}

This section will discuss the behaviour of the volatile components of the third stage leach residue. The roasting step is specifically included in the new pyrometallurgical process to remove the volatile elements. Os, $\mathrm{Se}, \mathrm{Te}, \mathrm{S}$, and As are volatile at low temperatures from a solid state in their respective pure oxides and therefore a low temperature oxidative roast is ideally suited to remove these elements. The following elements are targeted as part of the roasting process and will be discussed individually - Os, Se, Te, S, and As. Even though Ag is not recovered in the Lonmin PMR process it will also be discussed.

The vapours from the roasting process on third stage leach residue are toxic. Exposure to $\mathrm{OsO}_{4}$ fumes are known to be toxic, resulting in irritation of the eyes and respiratory system. Chronic exposure will damage the liver, kidneys and skin. Exposure to $\mathrm{SeO}_{2}$ fumes are known to be toxic, with symptoms including skin and eye irritation, stomach disorders, metallic taste and bad breath (amongst others). Short term exposure to $\mathrm{SO}_{2}$ fumes may cause breathing difficulties, while long term exposure may cause chronic respiratory illness (US National Library of Medicine NLM website). To avoid human contact with the fumes, good capture and adequate treatment is necessary.

Osmium (Os) is also classified as a PGM, while $\mathrm{Au}$ is typically not grouped with the 6 Platinum group metals, although it is a precious metal. In some refineries, Os is not recovered, while Au is recovered in all cases. For this reason Os is discussed under the volatiles and Au under PGMs. Os is the most volatile element of the PGM group as an oxide, and the least as a metal. Pure Os can thermodynamically oxidize to $\mathrm{OsO}_{4}$ at room temperature and will completely vaporize from around $50^{\circ} \mathrm{C}$ (under equilibrium conditions), with vapour pressure of $\mathrm{OsO}_{4}$ increasing with temperature. Os is 
difficult to analyse accurately since it tends to oxidize during fusion. In this test work ICP-OES and XRF techniques were used for Os quantification. Even though there may be a significant assaying error involved, the trends of Os removal can be viewed as indicative. Os removal increases proportionally from $3 \%$ at $600^{\circ} \mathrm{C}$ to $71 \%$ at $1000^{\circ} \mathrm{C}$. Thyse et. Al. (2010) reported that Osmium is often found as very small alloy (together with Ru, sharing the HCP crystal structure) inclusions (as secondary growth in a locked matrix) in converter matte. The presence of small Os alloy inclusions was also found in the current SEM work on third stage leach residue material. Where Os could be analysed with the SEM EDS in the roasted product, oxygen was also present in the phase together with $\mathrm{Ru}$ and $\mathrm{Rh}$. Thermodynamic equilibrium modelling shows that Os forms several solid solutions with other precious metals in the absence of oxygen. The presence of Osmium in a solid solution could depress the activity and correspondingly the fugacity/ vapour pressure. No literature reference could be found for stable osmates that form and that will not display volatile behaviour.

Selenium (Se) is volatile as an oxide $\left(\mathrm{SeO}_{2}\right)$ and removal of Se will require Se to oxidize to $\mathrm{SeO}_{2}$. Modelling shows Se can be completely removed, and the experimental test work shows that $\mathrm{Se}$ removal in the mid ninety percentage range is achievable. It appears that Se removal happens very rapidly and across the full temperature range of roasting. Some of the first crystals that de-sublimated onto the cooler portion of the off-gas duct was collected and analysed during the roasting test work. This was shown to be almost pure $\mathrm{SeO}_{2}$. Therefore, off-gas handling systems need to be designed to capture $\mathrm{SeO}_{2}$ via condensation/ de-sublimation.

Sulphur (S) is present in the third stage leach residue in the form of sulphides (copper and PGM sulphides) and sulphates (lead, nickel and copper sulphates). S removal during roasting will include the oxidation of the sulphides, as well as the dissociation of the sulphates. Table 2 explains the "Open" system modelling to be more accurate by allowing only partial oxidation and loss of $\mathrm{S}$ as $\mathrm{SO}_{2}$ from the system, instead of stabilizing sulphates. Table 11 shows that the "Open" FactSage modelling predicts $\mathrm{S}$ removal to proceed very similar to the experimental results. Above $800^{\circ} \mathrm{C}$, complete $\mathrm{S}$ removal is already achieved. The stability fields of transition metal sulphates decreases significantly with increasing temperature, as have been shown for numerous metals in Kellog $\left(\log \left[\mathrm{P}_{\mathrm{O} 2}\right]-\log \left[\mathrm{P}_{\mathrm{SO} 2}\right]\right)$ diagrams.

Table 11: FactSage prediction on sulphur weight change and sulphate decomposition (from the leach residue) compared to the actual sulphur weight change results.

\begin{tabular}{|c|c|c|c|c|c|c|c|c|c|}
\hline & $600^{\circ} \mathrm{C}$ & $650^{\circ} \mathrm{C}$ & $700^{\circ} \mathrm{C}$ & $750^{\circ} \mathrm{C}$ & $800^{\circ} \mathrm{C}$ & $850^{\circ} \mathrm{C}$ & $900^{\circ} \mathrm{C}$ & $1000^{\circ} \mathrm{C}$ & $1100^{\circ} \mathrm{C}$ \\
\hline $\begin{array}{c}\text { S removal } \\
\text { according to } \\
\text { FactSage } \\
\text { "Open" method }\end{array}$ & $-90 \%$ & $-91 \%$ & $-95 \%$ & $-97 \%$ & $-98 \%$ & $-100 \%$ & $-100 \%$ & $-100 \%$ & $-100 \%$ \\
\hline $\begin{array}{c}\text { S removal from } \\
\text { test work }\end{array}$ & $-83 \%$ & & $-95 \%$ & & $-98 \%$ & & $-100 \%$ & $-100 \%$ & \\
\hline $\begin{array}{c}\text { Temperature of } \\
\text { sulphate } \\
\text { decomposition } \\
\text { (rounded to } \\
\text { nearest } 50^{\circ} \mathrm{C} \\
\text { point) }\end{array}$ & $\begin{array}{c}\mathrm{Fe}_{2} \\
\left(\mathrm{SO}_{4}\right)_{3}\end{array}$ & $\mathrm{Ag}_{2} \mathrm{SO}_{4}$ & $\mathrm{MgSO}_{4}$ & $\begin{array}{c}(\mathrm{CuO}) \\
\left(\mathrm{CuSO}_{4}\right)\end{array}$ & $\mathrm{NiSO}_{4}$ & & $\mathrm{CaSO}_{4}$ & $\begin{array}{c}\left(\mathrm{PbO}^{\circ}\right) \\
\left(\mathrm{PbSO}_{4}\right)\end{array}$ \\
\hline
\end{tabular}


Tellurium ( $\mathrm{Te})$ is only volatile in the roasting test work temperature range as tellurite $\left(\mathrm{TeO}_{2}\right)$. Te will oxidize at low temperatures (even at room temperature) to $\mathrm{TeO}_{2}$, but the vapour pressure of $\mathrm{TeO}_{2}$ only becomes appreciable above $700^{\circ} \mathrm{C}$. Based on thermodynamic modelling, $\mathrm{TeO}_{2}$ show a strong relationship between the extent of removal and the volume of the gas phase that is in contact with the sample due to the relatively low vapour pressure of $\mathrm{TeO}_{2}$. Of the different volatile species concerned in this residue, $\mathrm{Te}$ is the only one that displays such a strong correlation to gas volume and temperature. The relationship (as modelled in FactSage) between the extent of removal, temperature and gas volume can be seen in Figure 6. Actual results from the roasting test work testifies to the improved extent of removal with longer retention times and better gas/ solid contact, both leading to higher carrier gas volumes in contact with the solid phase. The fluid bed roasting could achieve around $80 \%$ removal of $\mathrm{Te}$ at $900^{\circ} \mathrm{C}$, while the poor gas flow conditions and short retention times of the first set of experiments could only achieve $40 \%$ removal at $1000^{\circ} \mathrm{C}$. The experimental data shows that $99 \%$ Te removal could be achieved at $1000^{\circ} \mathrm{C}$ in a $40 \%$ oxygen atmosphere for $4 \mathrm{~h}$. Four data points at $900^{\circ} \mathrm{C}$ from the fluidized bed test work show low sensitivity of removal (between $70 \%$ and $77 \%$ achieved) with variable time and even oxygen potential. SEM EDS work on the roasted sample at $900^{\circ} \mathrm{C}$ showed that $\mathrm{Te}$ was often associated with high $\mathrm{Cu}$ and oxygen content.

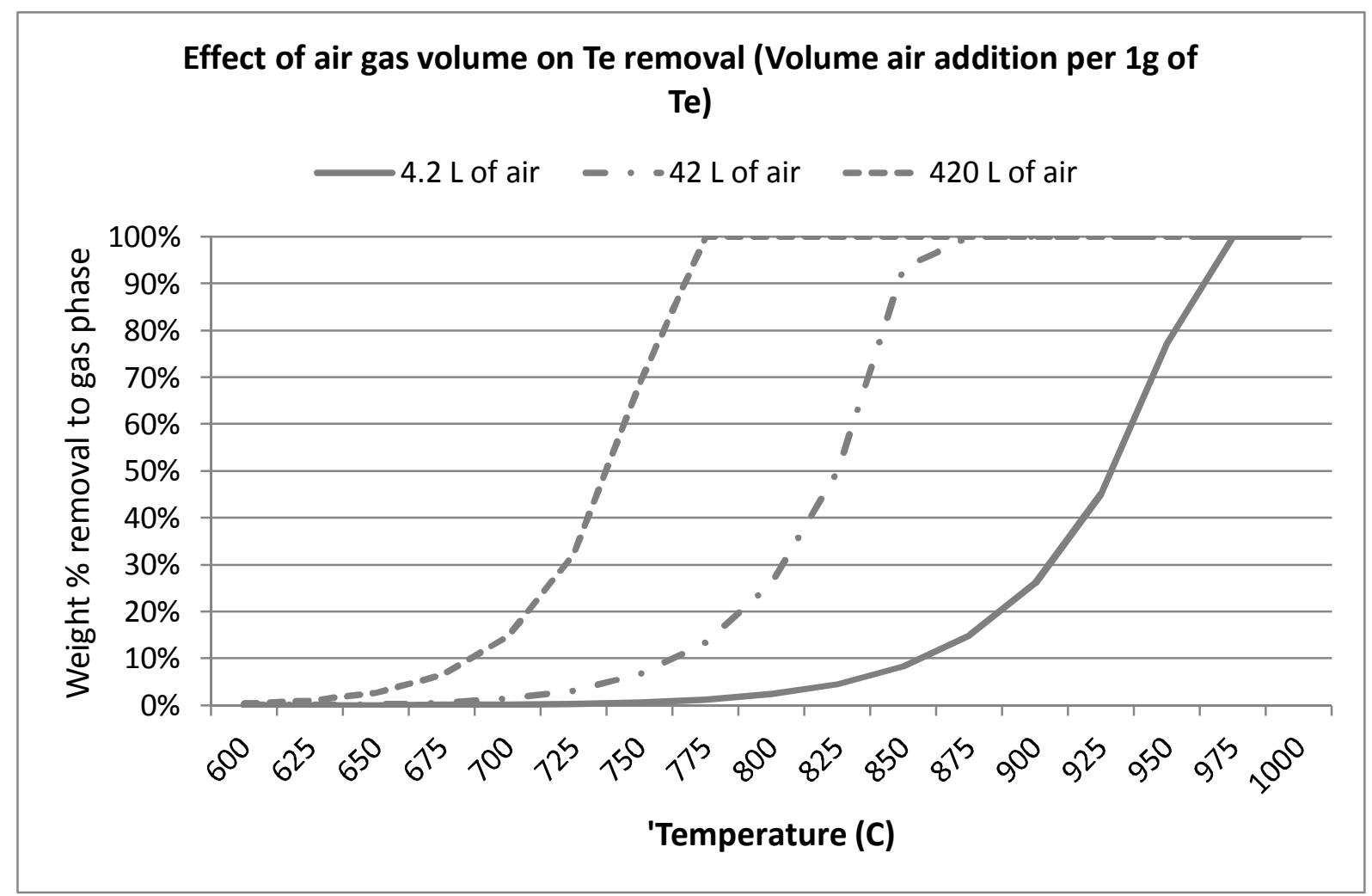

Figure 6: Effect of air volume on the removal of $\mathrm{TeO}_{2}$ to the gas phase according to FactSage modelling.

Table 12 below shows that Arsenic has the strongest thermodynamic driving force for oxidation (delta Gibbs free energy) at the low temperature range (up to around $800^{\circ} \mathrm{C}$ ) from the entire suit of elements present in the residue. 
Table 12: Delta Free Gibbs Energy for the pure element oxidation (expressed as Joule per mole solid reactant) as a function of the temperature to illustrate the relative strength of the driving force of the reaction.

\begin{tabular}{|c|c|c|c|c|c|}
\hline Reaction & $100^{\circ} \mathrm{C}$ & $300^{\circ} \mathrm{C}$ & $600^{\circ} \mathrm{C}$ & $800^{\circ} \mathrm{C}$ & $1000^{\circ} \mathrm{C}$ \\
\hline $\mathrm{Os}+2 \mathrm{O}_{2}=\mathrm{OsO}_{4}$ & -283250 & -250719 & -207292 & -178700 & -150355 \\
\hline $\mathrm{Se}+\mathrm{O}_{2}=\mathrm{SeO}_{2}$ & -157753 & -121275 & -115194 & -113015 & -110298 \\
\hline $\mathrm{Te}+\mathrm{O}_{2}=\mathrm{TeO} 2$ & -256266 & -221237 & -166563 & -130200 & -99105 \\
\hline $2 \mathrm{As}+1.5 \mathrm{O}_{2}=\mathrm{As}_{2} \mathrm{O}_{3}$ & -278555 & -252890 & -222135 & -203186 & -181032 \\
\hline $2 \mathrm{As}+2.5 \mathrm{O}_{2}=\mathrm{As}_{2} \mathrm{O}_{5}$ & -371345 & -323082 & -249657 & -199992 & -145785 \\
\hline $\mathrm{Pd}+\mathrm{O}_{2}=\mathrm{PdO}_{2}$ & -140392 & -103625 & -48527 & -11850 & 24778 \\
\hline $\mathrm{Pd}+0.5 \mathrm{O}_{2}=\mathrm{PdO}$ & -74904 & -55208 & -26363 & -7453 & 11262 \\
\hline $\mathrm{Rh}+\mathrm{O}_{2}=\mathrm{RhO}_{2}$ & -205821 & -210565 & -216950 & -220735 & -224130 \\
\hline $2 \mathrm{Rh}+1.5 \mathrm{O}_{2}=\mathrm{Rh}_{2} \mathrm{O}_{3}$ & -139500 & -112202 & -72327 & -46437 & -21118 \\
\hline
\end{tabular}

As is volatile as an oxide, and has 2 oxide forms, being $\mathrm{As}_{2} \mathrm{O}_{5}$ and $\mathrm{As}_{2} \mathrm{O}_{3}$ (sometimes expressed as $\mathrm{As}_{4} \mathrm{O}_{6}$ ). Arsenic will oxidize at room temperature in oxidizing environments. $\mathrm{As}_{2} \mathrm{O}_{5}$ is the most stable oxide at lower temperatures (up to about $790^{\circ} \mathrm{C}$ ), while $\mathrm{As}_{2} \mathrm{O}_{3}$ will be thermodynamically more stable above $790^{\circ} \mathrm{C}$. However, both these oxidation states will be present and FactSage predictions show that primarily $\mathrm{As}_{2} \mathrm{O}_{3}$ will volatilize. $\mathrm{As}_{2} \mathrm{O}_{5}$ solid should thermodynamically be stable in the residue till about $650^{\circ} \mathrm{C}$, after which all Arsenic should have joined the gas phase. The formation and thermal stability of metal arsenates $\mathrm{M}_{\mathrm{x}}\left(\mathrm{AsO}_{4}\right)^{3-}$ under oxidizing atmospheres is well known in the gold, copper and iron industry. The best known of the arsenates are $\mathrm{FeAsO}_{4}, \mathrm{Ca}_{3}\left(\mathrm{AsO}_{4}\right)_{2}$ and $\mathrm{Mg}_{3}\left(\mathrm{AsO}_{4}\right)_{2}$. The FactSage "Open" system predicts the formation of $\mathrm{Ca}_{3}\left(\mathrm{AsO}_{4}\right)_{2}$ between $650^{\circ} \mathrm{C}$ and $950^{\circ} \mathrm{C}$, thereby limiting the deportment of As to the gas phase to $94 \%$ (Table 2). Unfortunately the FactSage databases available to the author does not include $\mathrm{FeAsO}_{4}$ and $\mathrm{Mg}_{3}\left(\mathrm{AsO}_{4}\right)_{2}$. The presence of the ferric $(3+)$ ion stabilizes iron arsenate as scorodite, and the third stage leach residue will have the biggest portion of $\mathrm{Fe}$ present in the ferric state after the strong oxidising conditions experienced in the preceding acidic pressure leaching.

The roasting results from the stationary bed tests supports the viewpoint that a stable arsenic oxide specie forms at higher temperature, since the extent of removal of As drops from about $60 \%$ at $800^{\circ} \mathrm{C}$ to about $30 \%$ at $1000^{\circ} \mathrm{C}$. The fluidized bed test work shows a consistent removal of around $45 \%$ to $50 \%$ in the temperature range of $700^{\circ} \mathrm{C}$ to $900^{\circ} \mathrm{C}$. It seems that more residence time improves removal, but only marginally. The single data point in the fluid bed roast at $1000^{\circ} \mathrm{C}$ and $40 \%$ oxygen content shows the best extent of removal of $62 \%$. In order to test the hypothesis that a stable arsenate was limiting the volatile behaviour of arsenic oxide, reductive roasts were done by a combination of $\mathrm{N}_{2}$ and $\mathrm{CO}$ gas before and after the oxidative roast. However, no real improvement could be made on overall As removal when compared to doing only an oxidative roast. The presence of the remaining As in the roasted product was mostly in an oxidized phase associated with $\mathrm{Pb}, \mathrm{Ni}, \mathrm{Fe}$ and $\mathrm{Cu}$.

An investigation was done to see if a stable PGM arsenide could be responsible for the refractory nature of arsenic in the roasting step. A list of known minerals was investigated and modelled in FactSage, but none of the arsenides or sulpharsenides appears to be stable at the roasting temperatures in an oxidizing environment. Although a mechanism for arsenic stability in the leach residue cannot be presented at present, it seems that removal of around $50 \%$ can be achieved by roasting at temperatures of $850^{\circ} \mathrm{C}$ to $900^{\circ} \mathrm{C}$. 
Silver $(\mathrm{Ag})$ does not form stable oxides in the roasting temperature range. The vapour pressure of pure $\mathrm{Ag}$ can become sufficient at $1000^{\circ} \mathrm{C}$ to constitute some losses as $\mathrm{Ag}$ vapour to the gas phase, but the presence of the solid solution matrix seem to suppress this, so that no losses is predicted according to FactSage modelling. If sulphur is present in an oxidizing atmosphere, $\mathrm{Ag}_{2} \mathrm{SO}_{4}$ is present, but this decomposes between $650^{\circ} \mathrm{C}$ and $700^{\circ} \mathrm{C}$ and FactSage predict that all silver will to join the FCC solid solution phase. The SEM EDS work on the $900^{\circ} \mathrm{C}$ sample found some $\mathrm{Ag}$ associated with the oxidized $\mathrm{As}, \mathrm{Pb}, \mathrm{Ni}, \mathrm{Fe}, \mathrm{Cu}$ phase. Results from the stationary bed roasting test work shows that some Ag losses might start to occur at the high temperature of around $1000^{\circ} \mathrm{C}$. The fluidized bed roasting results are extremely variable, and it is not clear if the results might be influenced by sampling/ analytical error.

\section{Discussion of $\mathrm{Pb}$ compounds behaviour in the $600^{\circ} \mathrm{C}$ to $1000^{\circ} \mathrm{C}$ temperature range}

$\mathrm{Pb}$ is not volatile during the roasting process, but serves as a major contaminant in the PMR feed. Although the subsequent smelting step will target the removal of lead, it will shortly be discussed in order to understand final speciation.

Anglesite $\left(\mathrm{PbSO}_{4}\right)$ was detected in the feed sample with XRD (Table 4), but the Anglesite peak disappears at around $800^{\circ} \mathrm{C}$. The "Normal" Factsage system predicts that $\mathrm{Pb}$ will only be stable as a sulphate or an oxy-sulphate that will only decompose at around $1040^{\circ} \mathrm{C}$ which is higher than the roasting temperatures.

Thermodynamic modelling does not predict that the presence of a solid solution matrix will have any effect on the $\mathrm{Pb}$ decomposition, as $\mathrm{Pb}$ does not dissolve into the FCC solid solution. The SEM EDS analyses on the sample roasted at $900^{\circ} \mathrm{C}$ confirmed that $\mathrm{Pb}$ is present in an oxidized $\mathrm{As}, \mathrm{Cu}, \mathrm{Ni}, \mathrm{Fe}$ phase.

Both the near complete removal of $\mathrm{S}$ to the gas phase above $800^{\circ} \mathrm{C}$, together with the disappearance of the Anglesite peak do not support a stable lead sulphate presence. In the absence of a heat stable sulphate phase, no clear explanation can be provided for the lack of $\mathrm{Pb}$ removal to the gas phase.

\section{Discussion of stable oxide compounds behaviour in the $600^{\circ} \mathrm{C}$ to $1000^{\circ} \mathrm{C}$ temperature range}

Table 13 shows the stable oxides weight percentage content as a function of temperature according to FactSage modelling. 
Table 13: FactSage prediction on stable oxide speciation as a function of temperature (values expressed as wt\%).

\begin{tabular}{|c|c|c|c|c|c|c|c|c|c|}
\cline { 2 - 9 } \multicolumn{1}{c|}{} & $600^{\circ} \mathrm{C}$ & $650^{\circ} \mathrm{C}$ & $700^{\circ} \mathrm{C}$ & $750^{\circ} \mathrm{C}$ & $800^{\circ} \mathrm{C}$ & $850^{\circ} \mathrm{C}$ & $900^{\circ} \mathrm{C}$ & $950^{\circ} \mathrm{C}$ & $1000^{\circ} \mathrm{C}$ \\
\hline $\mathrm{CuSO}_{4}$ & 10.8 & 10.8 & 0.0 & 0.0 & 0.0 & 0.0 & 0.0 & 0.0 & 0.0 \\
\hline $\mathrm{NiSO}_{4}$ & 8.0 & 8.0 & 8.0 & 8.0 & 8.0 & 0.9 & 0.0 & 0.0 & 0.0 \\
\hline $\mathrm{Fe}_{2} \mathrm{O}_{3}$ & 5.2 & 7.4 & 7.4 & 0.0 & 0.0 & 0.0 & 0.0 & 0.0 & 0.0 \\
\hline $\mathrm{SiO}_{2}$ & 0.0 & 0.0 & 0.0 & 0.0 & 0.0 & 0.0 & 2.9 & 2.9 & 2.9 \\
\hline $\mathrm{MgSiO}_{3}$ & 0.0 & 0.0 & 0.0 & 0.0 & 0.8 & 0.8 & 0.8 & 0.8 & 0.0 \\
\hline $\mathrm{Ni}_{2} \mathrm{SiO}_{4}$ & 0.0 & 0.0 & 0.0 & 0.0 & 0.0 & 0.0 & 0.6 & 0.6 & 0.6 \\
\hline $\mathrm{MgSiO}_{3}$ & 0.0 & 0.0 & 0.0 & 0.0 & 0.0 & 0.0 & 0.0 & 0.0 & 0.8 \\
\hline$(\mathrm{NiO})\left(\mathrm{Fe}_{2} \mathrm{O}_{3}\right)$ & 0.0 & 0.0 & 0.0 & 0.0 & 0.0 & 10.8 & 10.8 & 10.8 & 10.8 \\
\hline$(\mathrm{CuO})\left(\mathrm{Fe}_{2} \mathrm{O}_{3}\right)$ & 0.0 & 0.0 & 0.0 & 11.0 & 11.0 & 0.0 & 0.0 & 0.0 & 0.0 \\
\hline$(\mathrm{CoO})\left(\mathrm{Cr}_{2} \mathrm{O}_{3}\right)$ & 0.0 & 0.3 & 0.3 & 0.3 & 0.3 & 0.3 & 0.3 & 0.3 & 0.3 \\
\hline$(\mathrm{MgO})\left(\mathrm{Cr}_{2} \mathrm{O}_{3}\right)$ & 0.0 & 0.0 & 0.0 & 0.3 & 0.3 & 0.3 & 0.3 & 0.3 & 0.3 \\
\hline $\mathrm{Mg}_{2} \mathrm{Al}_{4} \mathrm{Si}_{5} \mathrm{O}_{18}$ & 0.0 & 0.0 & 1.4 & 1.4 & 1.4 & 1.4 & 1.4 & 1.4 & 1.4 \\
\hline
\end{tabular}

There are a number of stable oxides in the third stage leach residue, namely the oxides of $\mathrm{Si}, \mathrm{Cr}, \mathrm{Fe}$, $\mathrm{Ni}, \mathrm{Cu}, \mathrm{Ca}, \mathrm{Al}$ and $\mathrm{Mg}$. Table 13 shows some of the major oxides species as they go through phase changes when the temperature increases. Firstly, the $\mathrm{Cu}$ and Ni sulphates decompose to leave Ni and $\mathrm{Cu}$ free to form stable oxides. In the case of $\mathrm{Ni}$, most $\mathrm{Ni}$ ends up as Trevorite in the spinel structure $\mathrm{NiO} . \mathrm{Fe}_{2} \mathrm{O}_{3}$. The SEM EDS work on the sample roasted at $900^{\circ} \mathrm{C}$ confirmed the presence of trevorite spinels. However, $\mathrm{Ni}$ was found in an abundant oxidized phase of $\mathrm{As}, \mathrm{Pb}, \mathrm{Ni}, \mathrm{Cu}$. In the case of $\mathrm{Cu}$, the spinel structure $\mathrm{CuO} \cdot \mathrm{Fe}_{2} \mathrm{O}_{3}$ disappears and $\mathrm{Cu}$ joins the $\mathrm{FCC}$ solid solution phase between $800^{\circ} \mathrm{C}$ and $900^{\circ} \mathrm{C}$ according to FactSage. SEM EDS analysis on the sample roasted at $900^{\circ} \mathrm{C}$ did not show any $\mathrm{Cu}$ in the metallic FCC solid solution phase, primarily consisting of Pt, Pd and some Rh. SEM EDS showed that $\mathrm{Cu}$ was distributed consistently in the $\mathrm{As}, \mathrm{Pb}, \mathrm{Fe}, \mathrm{Ni}$ and $\mathrm{Fe}$ rich phase.

The measurement in Table 4 of 38\% trevorite spinel phase could be explained if another spinel type phase was refined as trevorite. The oxidized $\mathrm{As}, \mathrm{Pb}, \mathrm{Ni}, \mathrm{Fe}$ and $\mathrm{Cu}$ phase observed in the SEM work could potentially have been refined as trevorite, as it is rich in Fe, Ni and $\mathrm{O}$. In the geoscience field, several studies have shown that both $\mathrm{Ru}$ and $\mathrm{Rh}$ are highly compatible and can be incorporated into spinel structures. For example, the phase $\mathrm{CuRh}_{2} \mathrm{O}_{4}, \mathrm{Mg}(\mathrm{Rh}, \mathrm{Ru})_{2} \mathrm{O}_{4}, \mathrm{Cr}(\mathrm{Rh}, \mathrm{Ru})_{2} \mathrm{O}_{4}$ has the spinel structure and can form when $\mathrm{Rh}$ and $\mathrm{Ru}$ is present under conditions where spinel type structures are allowed to crystallize (Capobianco et. al, 1990). These PGM containing spinels can be prepared by reacting $\mathrm{Ru}$ and $\mathrm{Rh}$ metal with an oxide phase, if left at temperature $\left(1000^{\circ} \mathrm{C}\right.$ to $\left.1450^{\circ} \mathrm{C}\right)$ for sufficient time (normally some days). $\mathrm{CuRh}_{2} \mathrm{O}_{4}$ can be prepared by mixing cupric nitrate with solid $\mathrm{Rh}_{2} \mathrm{O}_{3}$, drying and annealing between $700^{\circ} \mathrm{C}$ and $900^{\circ} \mathrm{C}$ (Ismunandar, B. et al, 1999). Spinel phases, especially chromite is known to be a concentrator of $\mathrm{Ru}$ and $\mathrm{Rh}$. The presence of the ferric ion $\left(\mathrm{Fe}^{3+}\right)$ improves the portioning of Ru to the spinel phase (Brenan, J., et al., 2012). SEM EDS work confirmed the presence of small amounts of $\mathrm{Ru}$ and $\mathrm{Rh}$ (between $1 \%$ and 3\%) in the oxidized $\mathrm{As}, \mathrm{Pb}, \mathrm{Ni}, \mathrm{Fe}$ and $\mathrm{Cu}$ phase. No $\mathrm{Ru}$ or $\mathrm{Rh}$ was measured in any of the inclusions that had a clear spinel form and stoichiometry.

If $\mathrm{Ru}$ or $\mathrm{Rh}$ is incorporated in the refractory spinel phase, it will affect the leachability in subsequent dissolution steps. The process developed by Western Platinum Ltd allows for a smelting step subsequent to the roasting step, in order to collect all PGMs in an alloy phase. Thermodynamically, PGMs have not been found to form stable spinel minerals. 
Silica $\left(\mathrm{SiO}_{2}\right)$ will have the opportunity to recrystallize at roasting temperatures. The quartz phase is stable between room temperature and $867^{\circ} \mathrm{C}$, after which the phase transformation to tridymite will take place. The phase transformation to cristobalite will only take place at $1465^{\circ} \mathrm{C}$ and the measurement of cristobalite in Table 4 might be explained by the fact that cristobalite, although metastable, forms in preference to tridymite in high temperature experiments, even in the stability range of tridymite. The presence of silica is consistent with routine assaying of BMR concentrate and originates when slag is imperfectly separated from matte during converter matte granulation.

\section{CONCLUSION}

Roasting of PGM concentrate in air at temperatures between $800^{\circ} \mathrm{C}$ and $900^{\circ} \mathrm{C}$ is an effective way to remove volatile impurities namely $\mathrm{Se}, \mathrm{Te}, \mathrm{S}$, Os and As to varying efficiencies. Thermodynamic equilibrium modelling proved to be a useful tool to estimate the behaviour of most elements and minerals, although a number of findings could not be interpreted by the literature that was reviewed or FactSage modelling. Further investigation is merited into the poor extent of removal of Osmium and Arsenic from the BMR residue, the poor removal efficiency of $\mathrm{Pb}$ (in the absence of a sulphate phase) and the potential inclusion of $\mathrm{Ru}$ and $\mathrm{Rh}$ in the spinel phase. The multi-element complex nature of the pressure leach residue and the complex transitions that occur during heating and roasting makes the analyses of results extremely complex, so that a combined approach of thermodynamic modelling, $\mathrm{XRD}$, SEM-EDS, SDTA is required to deconvolute the complexity of the materials and the thermochemical tansitions. The amorphous nature and very fine particulate sizes of a leach residue from an oxidative pressure leach step makes the identification of mineral speciation and association very difficult.

Iridium, Rhodium, Ruthenium and Palladium tends to oxidize at the lower temperatures. The dissociation temperature of Rh appears to be influenced by the presence of a metallic FCC solid solution phase that has time to crystallize at roasting temperatures. Although the vapour pressure of the PGM oxides are several orders of magnitude higher than the metal state (apart from Palladium), no losses of the PGMs to the vapour phase were measured. Further refining of the calcine from the roast is possible during a smelting stage with an engineered slag composition, which will be reported at a later stage.

\section{ACKNOWLEDGEMENTS}

The authors wish to express their gratitude to the assistance of the University of Pretoria and Outotec for their support and commitment to the success of the roasting trials. Gratitude is also expressed to ALS Chemex for the SEM analysis that was completed in a short time. The permission from Lonmin (Western Platinum Ltd) to publish this paper is also much appreciated.

\section{REFERENCES}

Bale C.W., Chartrand P., Degterov S.A., Ben Mahfoud R., Melançon J., Pelton A.D., Eriksson G., Hack K., Petersen S., FactSage Thermochemical Software and Databases, 2001 
Brenan J.M., Finnigan G.F., McDonough W.F., Homolova V., Experimental constraints on the partitioning of $\mathrm{Ru}, \mathrm{Rh}, \mathrm{Ir}, \mathrm{Pt}$ and $\mathrm{Pd}$ between chromite and silicate melt: The importance of ferric iron, Original Research Article,Chemical Geology, Volumes 302-303, 2 April 2012, pp 16-32

Capobianco C.J., Drake M.J., Partitioning of ruthenium, rhodium, and palladium between spinel and silicate melt and implications for platinum group element fractionation trends, Volume 54, Issue 3, March 1990, pp 869-874

Crundwell, F., Moats, M.S., Ramachandran, V., Robinson, T.G., Davenport, W.G., Extractive Metallurgy of Nickel, Cobalt and Platinum-Group Metals, 2011, Elsrivier, pp. 489-534

Dorfling, C., Akdogan, G., Bradshaw, S.M., Eksteen, J.J., 2011, Determination of the relative leaching kinetics of $\mathrm{Cu}, \mathrm{Rh}, \mathrm{Ru}$ and $\mathrm{Ir}$ during the sulphuric acid pressure leaching of leach residue derived from $\mathrm{Ni}-\mathrm{Cu}$ converter matte enriched in platinum group metals, Minerals Engineering, 24(6), pp. 583-589

Ismunandar, I., Kennedy, J.B., Hunter, B.A., Phase Transformation in the $\mathrm{CuRh}_{2} \mathrm{O}_{4}$ : A Powder Neutron Diffraction Study, Materials Research Bulletin, Vol. 34, No. 1, pp. 135-143, 1999

Jehn, H., High Temperature Behaviour of Platinum Group Metals in Oxidizing Atmospheres, Journal of less-common metals, No. 100, 1984, pp 321-339.

Kleeberg, R and Bergmann, J, Quantitative phase analysis using the Rietveld method and a fundamental parameter approach, in Powder Diffraction: Proceedings Second International School on Powder Diffraction, 2002 (eds: S P Sengupta and P Chatterjee) pp63-67.

Righter, K., Campbell A.J., Humayun, M., Hervig,R.L., Partitioning of Ru, Rh, Pd, Re, Ir, and Au between Cr-bearing spinel, olivine, pyroxene and silicate melts Original Research Article, Geochimica et Cosmochimica Acta, Volume 68, Issue 4, 15 February 2004, pp 867-880

Smith, S., Mineralogical analyses of BMR residues, Internal report from ALS Chemex to Lonmin, 7 September 2012

Thyse, E., Akdogan,G., Eksteen, J.J., The effect of changes in iron-endpoint during Peirce-Smith converting on PGE-containing nickel converter matte mineralization, Minerals Engineering, Vol. 24, No. 7, 2010.

U.S National Library of Medicine: http://www.nlm.nih.gov/pubs/factsheets/sis.html

Van Schalkwyk, R.F., Eksteen, J.J., Petersen, J., Thyse E.L., Akdogan, G., 2011, An experimental evaluation of the leaching kinetics of PGM-containing Ni-Cu-Fe-S Peirce Smith converter matte, under atmospheric leach conditions, Minerals Engineering, 24(6), pp. 524-534

Vines, R. F., Wise, E. M., The Platinum Metals and Their Alloys, The International Nickel Company, 1941, pp. 93-94 